\title{
Aspartic Proteases and Major Cell Wall Components in Candida albicans Trigger the Release of Neutrophil Extracellular Traps
}

\author{
Marcin Zawrotniak ${ }^{1}$, Oliwia Bochenska ${ }^{2}$, Justyna Karkowska-Kuleta ${ }^{1}$, \\ Karolina Seweryn-Ozog ${ }^{1}$, Wataru Aoki ${ }^{3}$, Mitsuyoshi Ueda ${ }^{3}$, Andrzej Kozik ${ }^{2}$ and \\ Maria Rapala-Kozik ${ }^{\text {t* }}$
}

${ }^{1}$ Department of Comparative Biochemistry and Bioanalytics, Faculty of Biochemistry, Biophysics and Biotechnology, Jagiellonian University, Krakow, Poland, ${ }^{2}$ Department of Analytical Biochemistry, Faculty of Biochemistry, Biophysics and Biotechnology, Jagiellonian University, Krakow, Poland, ${ }^{3}$ Division of Applied Life Sciences, Graduate School of Agriculture, Kyoto University, Kyoto, Japan

Neutrophils use different mechanisms to cope with pathogens that invade the host organism. The most intriguing of these responses is a release of neutrophil extracellular traps (NETs) composed of decondensed chromatin and granular proteins with antimicrobial activity. An important potential target of NETs is Candida albicans -an opportunistic fungal pathogen that employs morphological and phenotype switches and biofilm formation during contact with neutrophils, accompanied by changes in epitope exposition that mask the pathogen from host recognition. These processes differ depending on infection conditions and are thus influenced by the surrounding environment. In the current study, we compared the NET release by neutrophils upon contact with purified main candidal cell surface components. We show here for the first time that in addition to the main cell wall-building polysaccharides (mannans and $\beta$-glucans), secreted aspartic proteases (Saps) trigger NETs with variable intensities. The most efficient NET-releasing response is with Sap4 and Sap6, which are known to be secreted by fungal hyphae. This involves mixed, ROS-dependent and ROS-independent signaling pathways, mainly through interactions with the CD11b receptor. In comparison, upon contact with the cell wall-bound Sap9 and Sap10, neutrophils responded via a ROS-dependent mechanism using CD16 and CD18 receptors for protease recognition. In addition to the Saps tested, the actuation of selected mediating kinases (Src, Syk, $\mathrm{PI3K}$, and ERK) was also investigated. $\beta$-Glucans were found to trigger a ROS-dependent process of NET production with engagement of Dectin-1 as well as CD11b and CD18 receptors. Mannans were observed to be recognized by TLRs, CD14, and Dectin-1 receptors and triggered NET release mainly via a ROS-independent pathway. Our results thus strongly suggest that neutrophils activate NET production in response to different candidal components that are presented locally at low concentrations at the initial stages of infection. However, NET release seemed to be blocked by increasing numbers of fungal cells.

Keywords: neutrophil extracellular traps (NETs), Candida albicans, host defense, secreted aspartic proteases, mannans, glucans, fungal cell wall proteins 


\section{INTRODUCTION}

Candida albicans is a common opportunistic fungal pathogen in humans that causes frequent superficial mucosal infections and, particularly in immunocompromised individuals, systemic infections (candidiasis) that can lead to sepsis and consequently death (Lichtenstern et al., 2015; Lagunes and Rello, 2016). The ability of C. albicans to infect different host niches is a consequence of its incredible adaptability to variable surrounding environments through morphogenetic and phenotypic switching from non-invasive yeast-like cells to a more virulent filamentous hyphal form (Calderone and Fonzi, 2001). This adaptability is also based on the ability of C. albicans to form biofilms on artificial and natural surfaces within the host organism. In all of these processes, $C$. albicans undergoes a continuous remodeling of its cell wall architecture via the activation of a wide range of virulence factors. The principal compounds exposed on the fungal cell surface, such as mannans and $\beta$-glucans, represent the main epitopes through which human host immune receptors respond to fungal infections (Chaffin et al., 1998; Collette and Lorenz, 2011). The other important group of surface compounds are proteins such as adhesins in the agglutinin-like sequence (Als) protein family which have a broad binding specificity for many human proteins (Liu and Filler, 2011; Karkowska-Kuleta and Kozik, 2015). In addition are the so-called "moonlighting proteins," which are cytosolic proteins exposed on the fungal surface but whose function at this location remains unknown (Karkowska-Kuleta and Kozik, 2014).

Another group of candidal virulence factors includes a large family of secreted aspartic proteases (Saps) that not only facilitate the availability of nutrients for fungal growth (Mayer et al., 2013; Silva et al., 2014) but can also inactivate complement components (Gropp et al., 2009) and host antifungal peptides such as histatin or cathelicidin LL-37 (Rapala-Kozik et al., 2015; Bochenska et al., 2016), and cause the release of proinflammatory bradykininrelated peptides from kininogens (Rapala-Kozik et al., 2010; Kozik et al., 2015). Moreover, Saps are involved in the promotion of fungal cell adhesion to epithelial cells and tissues (Ibrahim et al., 1998). Saps also enable the escape and survival of fungal cells (Borg-von Zepelin et al., 1998) following an interaction with phagocytes and can serve as productive chemoattractants (Ran et al., 2013).

At the place of infection, C. albicans is detected by different immune cells, particularly by neutrophils (Netea et al., 2015). Neutrophils can kill microbes through phagocytosis, extracellularly through the release of antimicrobial factors via a degranulation process, or through the excretion of neutrophil extracellular traps (NETs) (Brinkmann et al., 2004). NETs are web-like structures that very effectively prevent pathogen spreading within the host and thus the further development of infections. NETs are composed of decondensed chromatin that is adorned with granular proteins such as elastase, myeloperoxidase (MPO), cathepsin G, and protease3, or with antibacterial peptides such as cathelicidin LL-37 (Brinkmann et al., 2004; Urban et al., 2009) that successfully combine to kill invading microbes.

NET formation, known as netosis, can be induced by bacteria, fungi, viruses, and parasites, as well as by activated platelets and some specific compounds such as cytokines, antibodies, and certain chemical substances. Netosis can also result from trauma (Brinkmann and Zychlinsky, 2012; Branzk and Papayannopoulos, 2013). The molecular mechanisms underlying netosis are still poorly understood but two main pathways have been described: (i) a classical mechanism that depends on the production of reactive oxygen species (ROS), with NADPH oxidase as the necessary signal mediator, and (ii) a rapid and ROS-independent mechanism (Rochael et al., 2015). The type of netosis pathway that is activated in different situations depends on the triggering factor and the receptors involved. The receptors involved in NET induction include the Toll-like receptors (e.g., TLR2, TLR4, CD14), C-lectin family (Dectin-1), complement receptors (CD11b/CD18; Mac-1), Fc-receptors (Fc $\gamma$ RIIIb), and others (Yipp et al., 2012; Mohanty et al., 2015; Aleman et al., 2016). Moreover, most of these molecules can also function as coreceptors (Aleman et al., 2016). The transduction of signals from receptors to the nucleus during NET induction engages many typical mediators including the spleen tyrosine kinase (Syk)/Src kinase family (Nanì et al., 2015), protein kinase C (PKC) (Neeli and Radic, 2013), extracellular signal-regulated kinases (ERK1/2) (Hakkim et al., 2011; Keshari et al., 2012; DeSouza-Vieira et al., 2016), phosphoinositide 3-kinase (PI3K) (Behnen et al., 2014; DeSouza-Vieira et al., 2016), and NADPH oxidase (Nishinaka et al., 2011; Parker et al., 2012). During netosis, the nuclear envelope is decomposed, the chromatin is decondensed and the DNA is complexed with different proteins released from ruptured granules. The cell membrane is subsequently ruptured and the NETs are released from the cells. Cytoplasmic proteins are rarely found in the NET structure, confirming that the protein/DNA complexes in NETs do not form via a random process (Urban et al., 2009).

C. albicans is readily recognized by neutrophils and the aspartic proteases produced by this microbe are chemotactic agents for neutrophils (Gabrielli et al., 2016) and are probably involved in their modulation via ROS generation (Hornbach et al., 2009). For the inactivation of fungal cells, neutrophils can also utilize netosis in which calprotectin seems to be the main killing component of NETs (Urban et al., 2006). Moreover, as the hyphal form of C. albicans appears to be too bulky to be phagocytosed, it has been proposed that NET release is activated and regulated by the size and type of morphological form of $C$. albicans and is therefore the ideal mechanism to prevent invasion by the filamentous forms of this pathogen (Branzk et al., 2014; Johnson et al., 2016). Furthermore, the major components of the C. albicans cell wall can be involved in the activation of netosis pathways. $\beta$-Glucans, which are recognized by the Dectin1 or CR3 receptors of neutrophils (Li X. et al., 2011; Gazendam et al., 2014; Johnson et al., 2016) cause NET release, probably via a ROS-independent mechanism (Byrd et al., 2013; Nanì et al., 2015). However, the detailed roles of each type of C. albicans surface or secreted component in NET formation are still poorly understood.

In our current study, we aimed to determine the functions of the main components of the $C$. albicans cell wall, including $\beta$ glucans, mannans and adhesive proteins, and Saps, in the process of NET formation. We found evidence that each major class of 
compounds isolated from the fungal cell wall can activate netosis and revealed for the first time that the C. albicans Saps play an important role as a NET-release trigger. We identified the main receptors involved for each class of compounds that was examined in the present study and identified that the CD11b receptor interacts with Sap6, one of the main triggers of netosis. Taken together, our current findings have enabled us to propose a scheme for the signaling pathways involved in the induction of netosis by fungal pathogens.

\section{MATERIALS AND METHODS}

\section{Yeast Strains and Culture}

The main experiments were performed using C. albicans strain ATCC10231 purchased from the American Type Culture Collection (Manassas, VA). The role of C. albicans Saps in netosis was also examined using the C. albicans strains listed in Table $\mathbf{1 .}$ C. albicans was grown in YPD medium (1\% yeast extract, $2 \%$ soybean peptone, and $2 \%$ glucose) for $16 \mathrm{~h}$ at $30^{\circ} \mathrm{C}$ in an orbital incubator to the stationary phase. For the isolation of cell wall components, C. albicans hyphae were obtained by inoculation of the stationary-phase cells into RPMI-1640 medium (PAA Laboratories $\mathrm{GmbH}$, Pasching, Austria) followed by incubation for $72 \mathrm{~h}$ at $37^{\circ} \mathrm{C}$ with constant shaking. To compare the NET release by two morphological forms of $C$. albicans, the same number of fungal cells was used in two sets. The yeast-like form was obtained directly from the YPD culture, after washing and re-suspending the cells in the PBS buffer, whereas the second set was incubated under hypha-inducing conditions (RPMI, $3 \mathrm{~h}$ at $37^{\circ} \mathrm{C}$ ), in which the cell number was kept nearly the same but the cell morphology changed. The initial cell count was determined by OD measurement at $600 \mathrm{~nm}$, performed for the diluted liquid culture and assuming that the $\mathrm{OD}_{600}$ value equal to 1 corresponds to $3 \times 10^{7}$ cells $/ \mathrm{ml}$.

\section{Neutrophil Isolation}

Human polymorphonuclear cells (PMNs) were isolated from EDTA-treated whole-blood samples obtained from healthy donors via the Regional Blood Donation Center (Krakow,

TABLE 1 | C. albicans strains used in this study.

\begin{tabular}{|c|c|c|}
\hline Strain & Genotype & References \\
\hline ATCC 10231 & Wild type & \\
\hline CAI-4 & Prototrophic wild type & $\begin{array}{l}\text { Fonzi and Irwin, 1993; } \\
\text { Murad et al., } 2000\end{array}$ \\
\hline $\operatorname{sap} \Delta / \Delta 1 / 2 / 3$ & $\begin{array}{l}\text { sap1 } \Delta:: \text { hisG/sap1 } \Delta:: h i s G \\
\text { sap2 } \Delta:: \text { hisG/sap2 } \Delta: \text { hisG } \\
\text { sap3 } \Delta:: \text { hisG/sap3 } \Delta: \text { hisG }\end{array}$ & Negri et al., 2011 \\
\hline $\operatorname{sap} \Delta / \Delta 4 / 5 / 6$ & 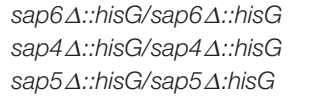 & Sanglard et al., 1997 \\
\hline $\operatorname{sap} 8 \Delta / \Delta$ & 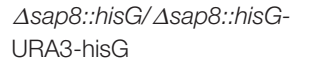 & Puri et al., 2012 \\
\hline $\operatorname{sap} \Delta / \Delta 9 / 10$ & $\begin{array}{l}\text { sap10 } 1: \text { hisG/sap10 } 1: \text { hisG } \\
\text { sap9 } \Delta: \text { hisG/sap9 } \Delta: \text { hisG }\end{array}$ & Albrecht et al., 2006 \\
\hline
\end{tabular}

Poland), which complies with the requisite confidentiality assurances for human participants. Whole blood $(20 \mathrm{ml})$ was collected into $50 \mathrm{ml}$ tubes containing EDTA at a final concentration of $5 \mathrm{mM}$. Samples were maintained at room temperature throughout the isolation procedure. The tubes were centrifuged at $300 \times \mathrm{g}$ for $15 \mathrm{~min}$, the plasma layer was removed, and the bottom layer containing leukocytes and erythrocytes was restored to the original volume of $20 \mathrm{ml}$ with phosphatebuffered saline (PBS) (Sigma-Aldrich, St. Louis, MO) and gently mixed by inverting the tube four times. The cell suspension was carefully layered on $10 \mathrm{ml}$ Pancoll (PAN-Biotech GmbH, Aidenbach, Germany) and centrifuged at $300 \times \mathrm{g}$ for $30 \mathrm{~min}$. The supernatant was removed and $20 \mathrm{ml}$ of $1 \%$ polyvinyl alcohol (Sigma-Aldrich) was gently mixed with the suspension by inverting four times. The tubes were allowed to stand for 20 min at room temperature to enable erythrocyte sedimentation. The supernatant containing the PMNs was then collected into a fresh tube and centrifuged at $110 \times \mathrm{g}$ for $5 \mathrm{~min}$. The supernatant was next removed and the erythrocytes in the cell pellet were lysed by the addition of $1 \mathrm{ml}$ of sterile $\mathrm{H}_{2} \mathrm{O}$ for $30 \mathrm{~s}$. An equivalent of $2 \mathrm{x}$-concentrated $\mathrm{PBS}$ was added to stop the lysis reaction. The volume of cell suspension was filled to $10 \mathrm{ml}$ by PBS and centrifuged at $110 \times \mathrm{g}$ for $5 \mathrm{~min}$. The supernatant was removed, the cell pellet was resuspended in $1 \mathrm{ml}$ RPMI-1640 medium without phenol-red (PAA Laboratories). The neutrophil purity was assessed routinely by forward- and side-scatter flow cytometric analyses and the rapid Romanowsky stain of cytospins followed by differential count of more than 700 cells, using optical microscopy. This neutrophil preparation method yields a $>95 \%$ pure population of the cells.

\section{Isolation of Mannans and Glucans from the C. albicans Cell Wall}

Mannans were isolated from the $C$. albicans cell wall using the method previously described by Kocourek and Ballou (1969). Briefly, this procedure is based on the precipitation of the mannans released from cell walls obtained after autoclaving the fungal cells for $3 \mathrm{~h}$ at $121^{\circ} \mathrm{C}$ in $20 \mathrm{mM}$ citrate buffer, $\mathrm{pH}$ 7.0. This precipitation of mannans from the supernatant was then repeated twice with Fehling's reagent obtained just before the experiment by mixing solution A $\left(69,278 \mathrm{~g} / \mathrm{l}\right.$ of $\mathrm{CuSO}_{4} \times 5$ $\left.\mathrm{H}_{2} \mathrm{O}\right)$ and $\mathrm{B}(346 \mathrm{~g} / \mathrm{l}$ of potassium-sodium tartrate and $100 \mathrm{~g} / \mathrm{l}$ of $\mathrm{NaOH}$ ). The remaining cell pellet, after homogenization, was used to isolate the glucans by heating the sample for $2 \mathrm{~h}$ in a water bath with isopropyl alcohol (w/v ratio of 1:4) under reflux. The excess reagent was removed by washing three times with acetone. Proteinaceous contaminations which can remain in the polysaccharide preparations were removed by hydrolyzing with $250 \mu \mathrm{g}$ of proteinase $\mathrm{K}$ (Sigma-Aldrich) for $4 \mathrm{~h}$ at $55^{\circ} \mathrm{C}$ in 20 $\mathrm{mM}$ Tris- $\mathrm{HCl}$ buffer, $\mathrm{pH} 8.0$ containing $20 \mathrm{mM} \mathrm{NaCl}, 2 \mathrm{mM}$ $\mathrm{MgCl}_{2}, 1 \mathrm{mM} \mathrm{CaCl}, 0.1 \mathrm{mM}$ DTT (Liu et al., 2008). Possible contamination of glucan and mannan fractions with other cell surface proteins was tested using the method of Bradford (1976). The concentration of mannans or glucans was determined using the phenol-sulfuric acid method (Dubois et al., 1951; Masuko et al., 2005), modified for 96-well microtiter plates (Sarstedt, 
Nümbrecht, Germany). About $200 \mathrm{ng}$ of glucans and $80 \mathrm{ng}$ of mannans could be obtained from $10^{5}$ cells.

\section{Isolation of C. albicans Cell Wall Proteins}

Cells from the hyphal form of C. albicans ( $0.4 \mathrm{~g}$ wet weight) were washed three times with $50 \mathrm{mM}$ phosphate buffer, $\mathrm{pH}$ 6.0, twice with $10 \mathrm{mM}$ Tris buffer with $0.9 \% \mathrm{NaCl}, \mathrm{pH}$ 7.4, and once with $50 \mathrm{mM}$ Tris buffer, $\mathrm{pH}$ 7.5. The extracts of cell wall proteins were prepared from cells by treatment with $\beta$-1,3-glucanase (Quantazyme; Qbiogene, Carlsbad, CA; Crowe et al., 2003). Quantazyme (200 U) was added to the cell suspension in $1 \mathrm{ml}$ of $50 \mathrm{mM}$ Tris buffer, $\mathrm{pH} 7.5$ containing $40 \mathrm{mM}$ 2-mercaptoethanol and protease inhibitor cocktail (Roche, Penzberg, Germany). The cells were then incubated at $37^{\circ} \mathrm{C}$ for $3 \mathrm{~h}$ with gentle shaking. Trypan Blue staining was used to verify that at least $95 \%$ of the C. albicans cells remained viable after this treatment. The treated cells were allowed to settle and after cell pellet removal, the released cell surface proteins in the supernatant were purified from DNA by ion chromatography on MonoQ-Sepharose (GE Healthcare/Pharmacia, Uppsala, Sweden) equilibrated in $20 \mathrm{mM}$ Tris- $\mathrm{HCl}$ buffer, $\mathrm{pH}$ 8.0. The protein fraction was then eluted using a gradient of $\mathrm{NaCl}(0-0.4 \mathrm{M})$ to receive cell wall protein mixture (CWP). The purification of Als3 and enolase was performed according to the method described by Seweryn et al. (2015).

\section{Recombinant Sap Production and Protein Fluorescent Labeling}

All 10 Sap isoenzymes used in the experiments were obtained according to the method described previously (Aoki et al., 2011; Rapala-Kozik et al., 2015), after their overexpression in the Pichia pastoris system (Invitrogen, Waltham, MA). The homogeneity of the purified proteins was checked by sodium dodecyl sulfate-polyacrylamide gel electrophoresis (SDS-PAGE) and their proteolytic activities were assayed on the borondipyrromethene FL casein substrate (Invitrogen) in $0.1 \mathrm{M}$ buffers at $\mathrm{pH}$ values corresponding to the highest activities of the enzymes (Aoki et al., 2011). Purified Sap6 was labeled using 5/6carboxyfluorescein succinimidyl ester (NHS-Fluorescein; Pierce Biotechnology, Rockford, IL). For the other protein samples $(200 \mu \mathrm{l})$, prepared in labeling buffer $(20 \mathrm{mM}$ sodium phosphate, $150 \mathrm{mM}$ sodium chloride, $\mathrm{pH} 8.0$ ), a 20 -fold molar excess of freshly prepared solution $(10 \mathrm{mg} / \mathrm{ml})$ of NHS-fluorescein in dimethylsulfoxide (DMSO) was added. The reactions were performed for $2 \mathrm{~h}$ on ice. Non-reacted NHS-fluorescein was removed using a Dye Removal Column (Pierce Biotechnology) by centrifugation for $30 \mathrm{~s}$ at $1,000 \times \mathrm{g}$. The concentration of labeled protein was determined with the bicinchoninic acid (BCA) method. Protein preparations were stored at $4^{\circ} \mathrm{C}$.

\section{NET Visualization}

Microscope slides were cleaned with isopropyl alcohol and coated with $0.01 \mathrm{mg} / \mathrm{ml}$ of poly-L-lysine at $4^{\circ} \mathrm{C}$ overnight. Then, 2.2 $\times 10^{5}$ neutrophils in $80 \mu \mathrm{l}$ RPMI-1640 medium were seeded on the slides and incubated for $30 \mathrm{~min}$ at $37^{\circ} \mathrm{C}, 5 \% \mathrm{CO}_{2}$ for cell attaching. Whole $C$. albicans cells or selected stimulants including isolated glucans, mannans, isolated mixture of cell wall proteins (CWP) or purified proteins (enolase, Als3, Saps) were then added in the volume of $20 \mu \mathrm{l}$ of RPMI at various range of concentrations. Neutrophils, treated for $3 \mathrm{~h}$ at $37^{\circ} \mathrm{C}$, $5 \% \mathrm{CO}_{2}$ with $25 \mathrm{nM}$ PMA (Sigma-Aldrich) were used as a positive control. After incubation, SytoxGreen dye (Molecular Probes, Eugene, OR) was added to each cell sample at a final concentration of $1 \mu \mathrm{M}$. Samples were visualized under a fluorescence microscope (Nikon Eclipse-Ti). NET production was also visualized using antibodies against myeloperoxidase or elastase (Abcam, Cambridge, UK).

\section{Monitoring of Neutrophil Interaction with C. albicans Cells or Their Surface Components via Quantification of the NET Response}

Twelve-well microplates (Greiner Bio-One, Germany) were coated with poly-L-lysine at $4^{\circ} \mathrm{C}$ overnight. An aliquot of $1.5 \times$ $10^{6}$ neutrophils in $900 \mu \mathrm{l}$ RPMI-1640 medium was added to each coated well and the cells were incubated at $37^{\circ} \mathrm{C}$ in $5 \% \mathrm{CO}_{2}$ for 30 min to enable attachment to the surface. Whole C. albicans cells, as well as stimuli factors including isolated glucans, mannans, whole CWP mixtures or purified proteins (enolase, Als3, Saps) were added in a volume of $20 \mu \mathrm{l}$ of RPMI at a selected range of concentrations. The cells were then further incubated at $37^{\circ} \mathrm{C}$ in $5 \% \mathrm{CO}_{2}$ for $3 \mathrm{~h}$. Cell treatment with PMA was used as a positive control. After incubation, the cells were washed three times with PBS. A $400 \mu \mathrm{l}$ aliquot of micrococcal nuclease (MNase) at a concentration of $1 \mathrm{U} / \mathrm{ml}$ (Roche) was then added and the cells were incubated at $37^{\circ} \mathrm{C}$ for an additional 20 min to digest any released DNA. The nuclease activity was stopped by the addition of $5 \mathrm{mM}$ EDTA. The microplate was finally centrifuged for $5 \mathrm{~min}$ at $300 \times \mathrm{g}$ at $4^{\circ} \mathrm{C}$ and the collected supernatants were once again centrifuged to remove any debris. SytoxGreen was added to the clarified solutions at a final concentration of $1 \mu \mathrm{M}$ and $50 \mu \mathrm{l}$ of each sample was transferred into a 96-well microplate to measure fluorescence (excitation at $495 \mathrm{~nm}$, emission at $525 \mathrm{~nm}$ ) using a Synergy H1 microplate reader (Biotek, Winooski, VT).

\section{Test of Neutrophil Viability}

Neutrophil apoptosis was analyzed using an annexin VFITC Apoptosis Detection Kit (ab14085, Abcam). Briefly, the neutrophils $\left(2.2 \times 10^{5}\right)$ were incubated with C. albicans cells at a multiplicity of infection (MOI) of $0.01-10$, at $37^{\circ} \mathrm{C}$ in $5 \% \mathrm{CO}_{2}$ for $3 \mathrm{~h}$. The cell suspensions were then washed three times with PBS and resuspended in $500 \mu \mathrm{l}$ of PBS containing annexin VFITC and propidium iodide (PI). Samples were further incubated for $5 \mathrm{~min}$ in the dark at room temperature and analyzed by flow cytometry using a FACS BD LSR II cytometer (BD, San Jose, CA) with a FITC signal detector for annexin V-FITC binding and phycoerythrin signal detector for PI staining.

\section{Analysis of Sap6 Interaction with Neutrophil Surface}

Neutrophils $\left(2.2 \times 10^{5}\right)$ in $100 \mu$ l of RPMI-1640 medium were transferred into a 96 -well high binding black microplate (Greiner Bio-One, Kremsmünster, Austria) and left at $37^{\circ} \mathrm{C}$ for $30 \mathrm{~min}$ 
to attach. The plate was then washed three times with $0.05 \%$ bovine serum albumin (BSA) in PBS and further incubated in this solution for $30 \mathrm{~min}$ at $37^{\circ} \mathrm{C}$ to coat the unoccupied well surface. After further washing of the cells with PBS, $100 \mu$ l aliquots of fluorescently labeled Sap6 at various concentrations were added to the wells. The plate was then incubated for $1 \mathrm{~h}$ at $37^{\circ} \mathrm{C}$ and washed three times with PBS. Fluorescence was measured $(465 / 525 \mathrm{~nm})$ in fresh PBS using the Synergy H1 microplate reader.

For microscopic analysis of neutrophil interaction with Sap6, $10^{5}$ neutrophils suspended in RPMI medium were settled for 30 min at $37^{\circ} \mathrm{C}$ on glass coverslips pre-coated with poly-L-lysine (1 $\mathrm{mg} / \mathrm{ml})$. Cells were incubated with fluorescein-labeled Sap6 for 1 $\mathrm{h}$ at $37^{\circ} \mathrm{C}$, washed with PBS and fixed with $3.7 \%$ formaldehyde for $10 \mathrm{~min}$ at room temperature. Glass slides were then washed twice with PBS. Mounting medium Fluoromount-G (Southern Biotech) was added to the preparations. The confocal microscopy images were collected using an TCS SP5 II microscope (Leica).

\section{Identification of the Neutrophil Receptors and Signal Mediators Involved in Netosis}

For investigation of the role of selected receptors or signal mediators in netosis, neutrophils were preincubated with specific antibodies or inhibitors prior to stimulation with $C$. albicans factors. Neutrophils $\left(1 \times 10^{6}\right)$ were preincubated for $30 \mathrm{~min}$ at $37^{\circ} \mathrm{C}$ in RPMI-1640 medium with $1 \mu \mathrm{g} / \mathrm{ml}$ of blocking antibodies directed against TLR2, TLR4, Dectin-1, CD14 (Invivogen, Toulouse, France), CD11a, CD11b, CD16, CD18 (BioLegend, San Diego, CA, USA) or isotype control antibody-IgG (Abcam). For the analysis of selected signaling pathways, neutrophils $\left(1 \times 10^{6}\right)$ were preincubated for $30 \mathrm{~min}$ at $37^{\circ} \mathrm{C}$ in RPMI-1640 medium with $30 \mu \mathrm{M}$ of Syk inhibitor (piceatannol; Sigma-Aldrich), 10 $\mu \mathrm{M}$ of Src inhibitor (PP2; Calbiochem, Darmstadt, Germany), $25 \mu \mathrm{M}$ of PI3K inhibitor (LY29004; Calbiochem), or $10 \mu \mathrm{M}$ of ERK inhibitor (UO126; Cell Signaling Technology, Beverly, MA). To inhibit ROS-dependent netosis pathways, neutrophils were preincubated for $30 \mathrm{~min}$ at $37^{\circ} \mathrm{C}$ in RPMI-1640 medium with $10 \mu \mathrm{M}$ DPI (Sigma-Aldrich), an NADPH oxidase inhibitor. Phagocytosis of neutrophils was blocked by pretreatment of the cells with $5 \mu \mathrm{M}$ of cytochalasin D (CytD, Sigma-Aldrich) for 15 $\min$ at $37^{\circ} \mathrm{C}$. After removal of the blocking agent by cell washing, neutrophils were treated with the indicated stimulants. Untreated neutrophils were used as controls.

\section{Analysis of ERK1/2 Activation}

ERK1/2 activation was analyzed using an ERK 1/2 (pT202/Y204 + Total) ELISA Kit (ab176660, Abcam). Neutrophils $\left(1 \times 10^{5}\right)$ were incubated in RPMI-1640 medium with selected Saps at a concentration of $1 \mathrm{ng} / \mathrm{ml}$ for $1 \mathrm{~h}$ at $37^{\circ} \mathrm{C}$ in $5 \% \mathrm{CO}_{2}$. The cells were then washed three times with PBS and lysed in lysis buffer containing phosphatase and protease inhibitors provided by the manufacturer. Fifty microliters of aliquots of each lysate were transferred into the wells of antibody pre-coated strips and 50 $\mu l$ of a solution containing antibodies coupled with peroxidase was added. The strips were then incubated for $1 \mathrm{~h}$ at room temperature with continuous gentle shaking. The wells were then washed three times with the provided buffer and the plate was incubated for an additional 15 min following the addition of $3,3^{\prime}, 5,5^{\prime}$-tetramethylbenzidine (TMB). The enzymatic reaction was stopped by acidification and the optical density (OD) was recorded for each well at $450 \mathrm{~nm}$ using the Synergy H1 microplate reader.

\section{Statistical Analysis}

Experiments were performed at least three times in duplicate using neutrophils from different donors on different days. Statistics were performed by one-way ANOVA analysis followed by Turkey's post-hoc test, using GraphPad Prism 7 software (GraphPad Software, La Jolla, CA, USA). Differences of $p<0.05$ were considered significant.

\section{RESULTS}

\section{The Main Virulence Factors of C. albicans are Involved in Triggering NET Formation}

Some recent studies have described the different involvement of two morphological forms of C. albicans cells in NET release by neutrophils upon contact with fungi, with a stronger effect found for the hyphal form (Urban et al., 2006; Branzk et al., 2014; Johnson et al., 2016). Although, all C. albicans cells are equipped with principal virulence factors such as cellwall polysaccharides (glucans, mannans), surface proteins and proteases (either surface-localized or secreted to the surrounding environments), the specific profiles and proportions of these factors are different and are dependent on the location and extent of infection (Naglik et al., 2008). To compare their efficiency in NET release, we used purified virulence factors isolated from the filamentous form of C. albicans. The effects on NET release after $3 \mathrm{~h}$ of neutrophil treatment were detected by SytoxGreen staining and were compared with the results observed during neutrophil contact with $25 \mathrm{nM}$ phorbol myristate acetate (PMA), a potent inducer of NETs, and corresponding to neutrophilcontacted whole fungal cells at an MOI 1:1. Our results (Figure 1) confirmed previous observations in the literature on the higher NET response levels to the filamentous forms of $C$. albicans as compared to planktonic cells. The most intense signal was detected with compounds that form the core of the fungal cell wall, i.e., mannans and glucans, and produced signals even exceeding the PMA effect (130 and 60\%, respectively). Weaker responses of neutrophils were found for proteinaceous fungal cell surface compounds, mainly mannoproteins (up to $60 \%$ ) involved in the adhesion of C. albicans cells, as well as the surface-attached protease Sap9 (48\%). The effect of Sap9 was comparable to that of Sap6 (35\%), which is the aspartic protease secreted to the environment by the hyphal form of $C$. albicans.

\section{NET Formation Is Determined by the Progress of $\boldsymbol{C}$. albicans Infection}

The previously reported data suggesting the impact of host proteins or the pathogen size on the quantity of NET release by neutrophils in contact with C. albicans (Branzk et al., 2014), and their possible influence on microbial biofilm formation (Johnson et al., 2016), prompted us to assess a possible correlation 


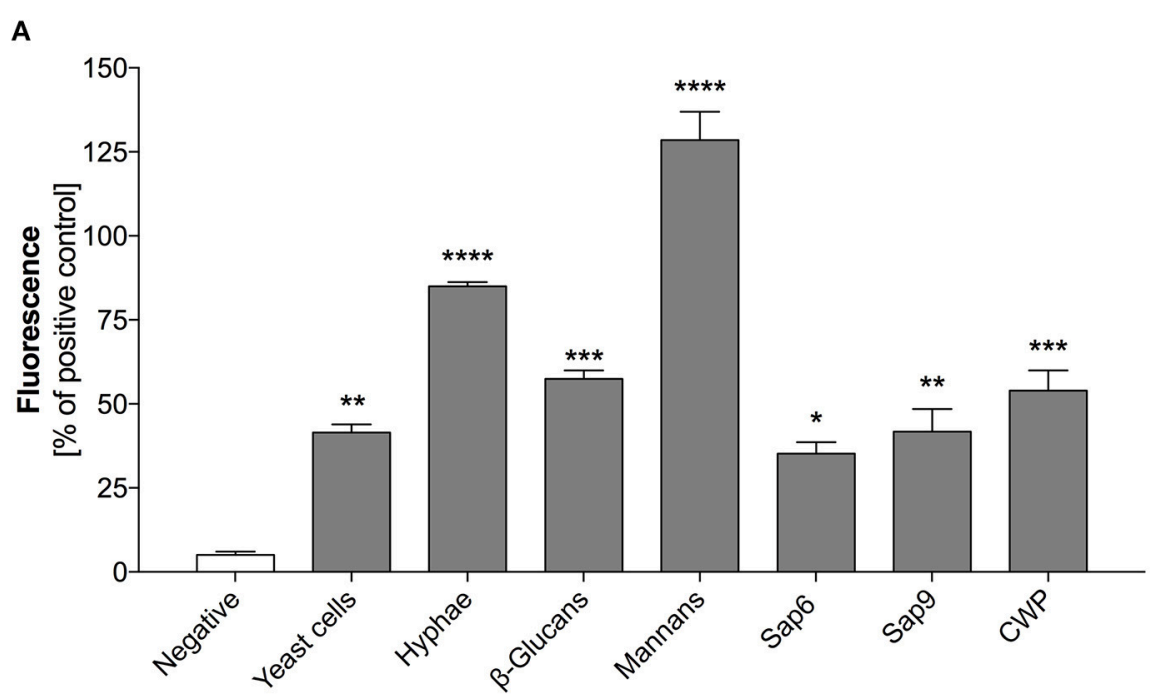

B
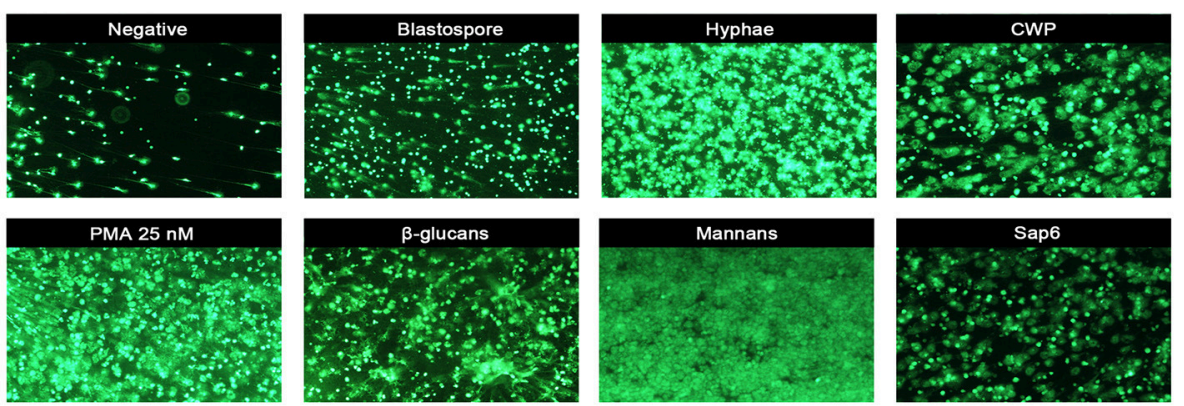

FIGURE 1 | NET release in response to selected C. albicans extracellular components. Neutrophils $\left(2.2 \times 10^{5}\right)$ in RPMI medium were treated for 3 h with solutions of purified C. albicans extracellular components: glucans, mannans, cell wall proteins (CWP) and Saps or whole $\mathrm{C}$. albicans cells, pre-propagated for $3 \mathrm{~h}$ at $37^{\circ} \mathrm{C}$ under different conditions (YPD or RPMI), to obtain representations of two fungal morphological forms (yeasts and hyphae, respectively) at an MOI of 1:1, as was described in detail in Materials and Methods section. Neutrophils treated with $25 \mathrm{nM}$ PMA were used as a positive control whereas untreated cells served as a negative control. (A) Extracellular DNA from neutrophils was partially digested with micrococcal nuclease (MNase) and quantified. The fluorescence intensity measured after Sytox Green treatment was used to quantify NET release relative to the positive control. The results shown are derived from three independent experiments performed in duplicate. Data represent the means (relative to PMA) \pm SEM. Asterisks denote a statistically significant difference between the samples and negative control $\left({ }^{*} p<\right.$ $0.05,{ }^{* *} p<0.01,{ }^{* \star *} p<0.005,{ }^{* \star \star \star} p<0.001$, ns - no significance). (B) Extracellular DNA was visualized by fluorescence microscopy after staining with SytoxGreen. The results shown are a representative of five independent experiments, each performed in triplicate.

between NET release and the progress of infection. We simulated infection progression by increasing the MOI (multiplicity of infection) of the contacting cells. For more precision and to eliminate the effect of biofilm formation we used planktonic cells that started to germinate during the time of contact with neutrophils ( $\left.3 \mathrm{~h}, 37^{\circ} \mathrm{C}, \mathrm{RPMI}\right)$. At a low amount of $C$. albicans cells (up to a 1:1 MOI), the alarmed neutrophils responded by increasing NET production, suggesting an important role of netosis at the initial infection stage (Figure 2A). However, further increases in the amount of fungal cells in contact with neutrophils (an MOI above 2:1) resulted in a declining NET release.

To test whether this observation was the result of different types of neutrophil death, we assessed neutrophil viability after exposure to C. albicans cells by FACS analysis (Figure 2B). The results indicated that the number of propidium iodide positive cells $(\mathrm{PI}+)$ correlated with netosis at different MOI values. At an MOI of 1:1 and 1:5 the percentage of PI+ cells reached the highest level, but at the MOI of 1:10 this trend was reversed, i.e., the number of living cells increased and NET production was not observed. This finding suggests the involvement of other mechanisms of defense against fungal cells.

\section{Glucans and Mannans Trigger NET Release by Different Mechanisms Involving Reactive Oxygen Species}

Based on the identified effects of $C$. albicans surface components on NET release, a deeper analysis was conducted to determine the receptor involvement and ROS-dependent nature of these responses. As the type and amount of glucans or mannans on the $C$. albicans cell surface may change during infection, depending on host cell response, we first assessed whether there 

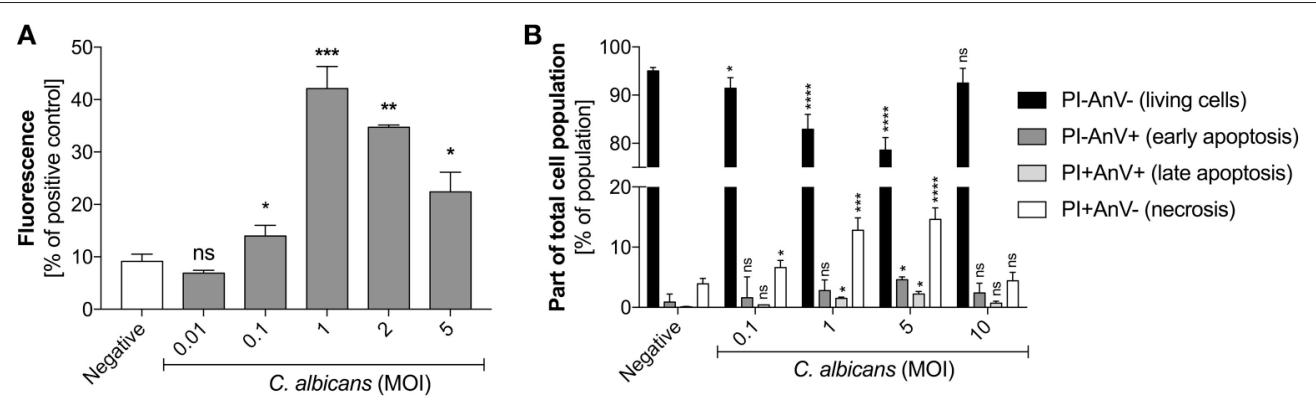

FIGURE 2 | (A) Generation of NETs by C. albicans at different MOI levels. (B) Neutrophil viability upon contact with C. albicans. (A) Neutrophils $\left(2.2 \times 10^{5}\right)$ were incubated with $\mathrm{C}$. albicans cells at different $\mathrm{MOl}$ levels for $3 \mathrm{~h}$ to induce netosis. After incubation, the amount of released DNA was determined using MNase for partial NET digestion followed by staining with SytoxGreen. Unstimulated neutrophils were used as a negative control; a $25 \mathrm{nM}$ PMA solution was assumed to induce a maximal level of NET release. Results from three independent experiments (in triplicate) are shown. Error bars represent the mean \pm SEM and are expressed as a percentage ratio of the tested sample signal relative to the PMA-induced control. Asterisks denote statistical significance relative to the negative control $\left({ }^{*} p<0.05\right.$, ${ }^{* *} p$ $<0.01,{ }^{* \star *} p<0.005,{ }^{* \star * *} p<0.001$, ns - not significant). (B) After incubation with C. albicans cells, neutrophils were labeled with annexin V-FITC and propidium iodide and analyzed by flow cytometry. The results are presented as a percentage ratio of the signal detected for whole cell population and showing no cell death (PI-AnV-), early apoptosis (PI-AnV+), and late apoptosis ( $\mathrm{PI}+\mathrm{AnV}+)$. Cells stained only with propidium iodide (PI+AnV-) represent the necrotic or NET-forming cells. For each sample, data were collected for 100,000 neutrophils. Data are presented as mean \pm SEM of three independent experiments. Asterisks denote statistical significance relative to the negative control $\left({ }^{\star} p<0.05,{ }^{* \star} p<0.01,{ }^{* \star *} p<0.005,{ }^{* \star * *} p<0.001\right.$, ns - not significant).

was any correlation between NET production and polysaccharide concentration (Figure 3). The amount of glucans and mannans used in these experiments corresponded to the estimated amounts on the fungal cell surface at an MOI of 1:1.

In the analysis, the presence of glucans at a concentration of up to $200 \mathrm{ng} / \mathrm{ml}$ (Figure 3A) led to the release of NETs in a dose-dependent manner. Surprisingly, further increases in the glucan concentration resulted in a significant decrease in the netosis yield. The most efficient NET production level, i.e., about $70 \%$ of total amount of DNA released after PMA stimulation, was observed for the glucan concentration of 200 $\mathrm{ng} / \mathrm{ml}$ that corresponds to an MOI of 1:1. Moreover, this glucantriggered process seemed to involve a ROS-dependent pathway, in which NADPH oxidase is the key mediator of NET release. This was evidenced by the effect of treating neutrophils with the NADPH oxidase inhibitor diphenyleneiodonium chloride (DPI) prior to glucan usage. DPI exposure caused a significant reduction in the neutrophil response, below $20 \%$ of the positive control level. This effect was similar to that detected using neutrophils treated with PMA in the presence of DPI, suggesting that this process is strongly ROS-dependent. A similar pattern of netosis activation was observed with mannans (Figure 3B). The maximal efficiency of NET production, about $60 \%$ of the positive control level, was detected at a mannan concentration of only $20 \mathrm{ng} / \mathrm{ml}$. Notably, a further increase in the mannan concentration also caused a lower NET response. However, the netosis pathway triggered by exposure to mannans seemed to differ from that induced by glucans. The inhibition of NADPH oxidase by DPI had little effect on NET formation in the presence of mannans, with a minor blocking impact of DPI on DNA release. This finding suggests that mannans act predominantly, but not exclusively, through an ROS-independent netosis pathway.

These two types of $C$. albicans polysaccharide cell wall components are recognized by various neutrophil receptors.
We therefore attempted to identify the receptors involved in the activation of netosis by glucans (Figure 4A) and mannans (Figure 4B). Specific antibodies were used to block a range of receptors prior to stimulation with glucans at concentration of $200 \mathrm{ng} / \mathrm{ml}$ or mannans at concentration of $20 \mathrm{ng} / \mathrm{ml}$. The decrease in NET response would then indicate the receptor participation in netosis activation by neutrophils. As shown in Figure 4A, an active role in the glucan-triggered process was shown for the CD369 (Dectin-1), CD11b (Mac-1), and CD18 receptors, in which CD11b and CD18 were found to be cooperating receptors. Antibody blocking of these receptors led to a $50-60 \%$ decrease in the NET response. A lowering in NET production was also observed for a CD11a receptor block, where incubation with a specific antibody decreased the extracellular DNA release to about $80-85 \%$ of the initial level.

In the case of mannan-triggered netosis, it was found to be mediated by many different surface receptors (Figure 4B), principally the CD369 (Dectin-1), CD11b (Mac-1), and CD14 receptors. CD14 is a co-receptor for TLR4, which, together with TLR2, also played a role in mannan recognition by neutrophils. A slight effect was also noted when blocking the CD18 and CD11a receptors. The considerable differences in the receptors involved in mannan-triggered netosis may explain the possible mixed mechanisms, i.e., ROS-independent and ROS-dependent, underlying the NET response to these molecules.

\section{C. albicans Surface Proteins Are Less Effective in Activating Netosis}

As identified in our earlier analyses, C. albicans surface proteins also participated in NET production by neutrophils in contact with $C$. albicans cells. To determine the ability of these surface proteins to activate NET release we purified those that have been commonly detected during C. albicans host infections. These included Als3-one the main candidal adhesins and a representative of the glycosylphosphatidylinositol 

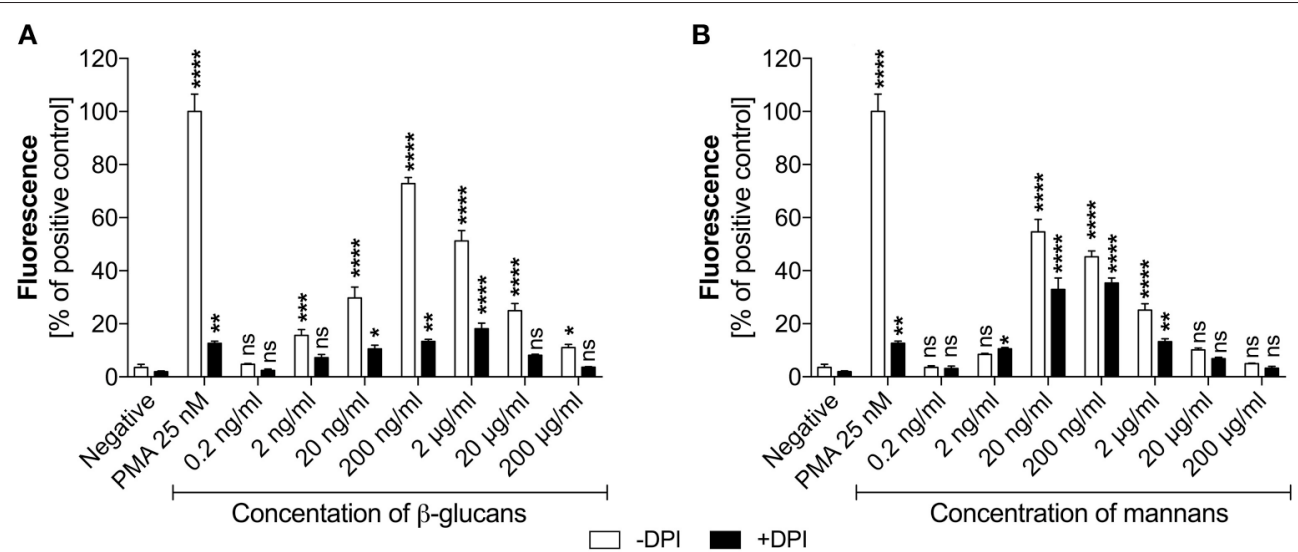

FIGURE 3 | Generation of NETs triggered by glucans and mannans. Neutrophils $\left(2.2 \times 10^{5}\right)$ were incubated for $3 \mathrm{~h}$ with isolated C. albicans glucans (A) or mannans (B) at the indicated concentrations to induce netosis. Cells with active NADPH oxidase (-DPI) or with this enzyme inhibited by $5 \mu$ M DPI (+DPI) were used. The amount of released DNA was determined fluorometrically after SytoxGreen staining, as described above. The negative control was unstimulated neutrophils, while treatment with $25 \mathrm{nM}$ PMA solution was assumed to induce a maximal NET release. The results shown are representative of three independent experiments performed in duplicate. Data represent the means \pm SEM and are shown as percentage ratio of the signal for the tested sample relative to the PMA-induced control. Asterisks denote statistical significance relative to the negative control $\left({ }^{\star} p<0.05,{ }^{\star \star} p<0.01,{ }^{\star \star \star} p<0.005,{ }^{\star \star \star \star} p<0.001\right.$, ns - not significant).
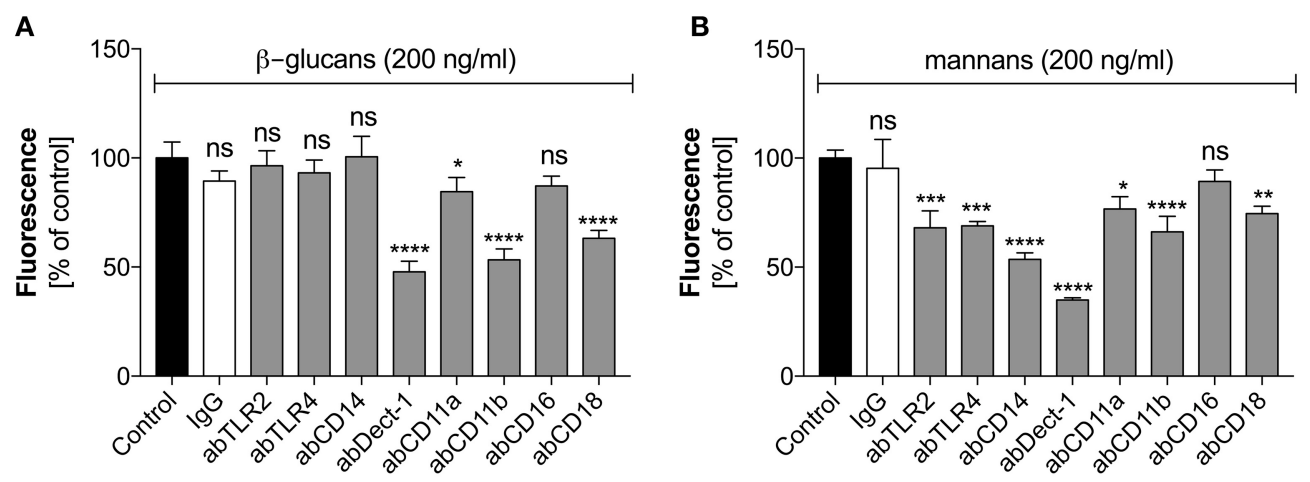

FIGURE 4 | The role of neutrophil receptors in the activation of netosis by glucans and mannans. Neutrophils $\left(2.2 \times 10^{5}\right)$ were preincubated with selected antibodies $(\mathbf{a b}, 1 \mu \mathrm{g} / \mathrm{ml})$ against the indicated surface receptors and netosis was then induced for $3 \mathrm{~h}$ by incubation with glucans (A) or mannans (B) at a concentration of 200 $\mathrm{ng} / \mathrm{ml}$. IgG antibody was used as the isotype control. The amount of released DNA was determined using SytoxGreen staining and fluorimetric detection, as described above. The results shown are derived from three independent experiments performed in duplicate. Data are represented by the means \pm SEM and are expressed as percentage ratio of the detected signal for the tested sample relative to the control sample. Asterisks denote statistical significance relative to the negative control $\left({ }^{*} p\right.$ $<0.05,{ }^{* \star} p<0.01,{ }^{\star \star \star} p<0.005,{ }^{\star \star \star \star} p<0.001$, ns - no significance).

(GPI)-anchored surface mannoproteins, and enolase, the most prominent "moonlighting" protein that has well-confirmed adhesive function (Liu and Filler, 2011; Karkowska-Kuleta and Kozik, 2014) and is a widely used antigen in serological tests for candidal infection (Li Wq. et al., 2011; Shibasaki et al., 2013). Both proteins were tested for their ability to stimulate NET formation in a concentration-dependent manner. Als3 did not show any significant influence on NET release (Figure 5A). In contrast, enolase showed a positive correlation with the NET response, but only within a narrow concentration range (Figure 5B). Enolase caused a maximal effect at $80 \mathrm{ng} / \mathrm{ml}$, releasing NETs at $30 \%$ of the positive control level. Again, a further increase in the enolase concentration in contact with neutrophils inhibited netosis.

\section{Aspartic Proteases of C. albicans Trigger Netosis with High Potency} Sap Production Mutants Are Less Effective in Activating NETs

To verify the role of secreted and surface localized aspartic proteases of C. albicans in the activation of netosis, we used C. albicans strains harboring selected Sap group gene deletions (Figure 6). We used the C. albicans CAI-4 strain as the reference. CAI-4 responded depending on the MOI in the same way as the wild-type ATCC10231 strain. We observed the highest efficiency of NET production at an MOI of 1:1, corresponding to $60 \%$ of the positive control level with PMA exposure. All of the mutant strains of $C$. albicans could initiate netosis in an MOI-dependent manner but they responded with different 

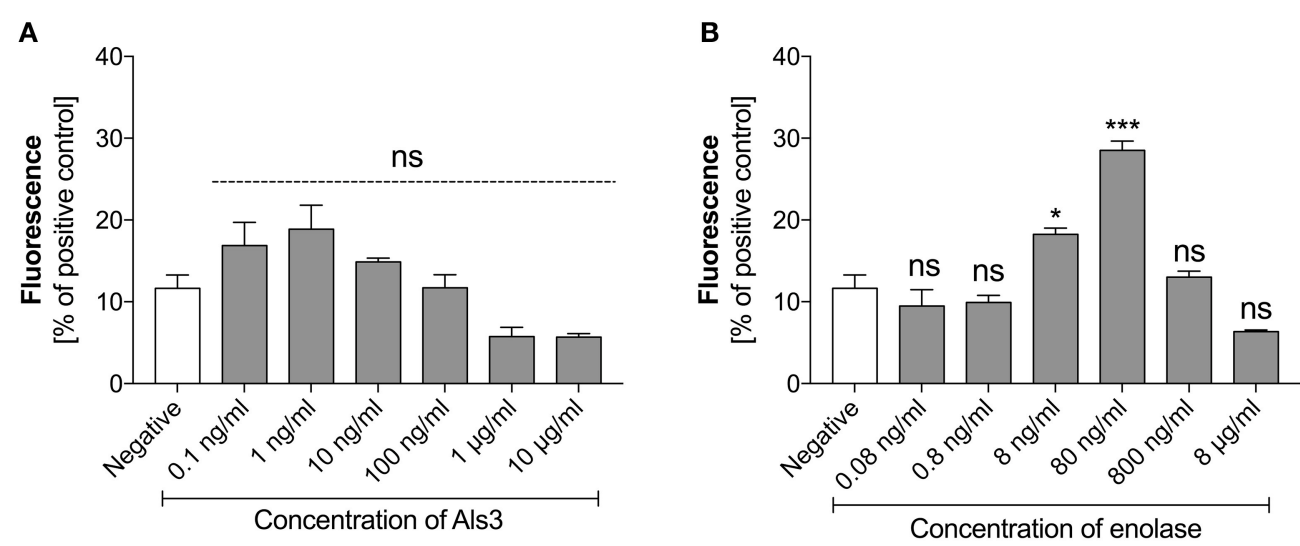

FIGURE 5 | Response of neutrophils to stimulation with Als3 and enolase. Neutrophils $\left(2.2 \times 10^{5}\right)$ were incubated with selected concentrations of Als3 (A) or enolase (B) for $3 \mathrm{~h}$ to induce netosis. The amount of released DNA was determined fluorimetrically after SytoxGreen staining, as described above. The results shown are derived from three independent experiments performed in duplicate. Data are presented as the means \pm SEM and expressed as a percentage ratio of the signal for the tested sample relative to the positive, PMA-induced control. Asterisks denote statistical significance relative to the negative control $\left({ }^{*} p<0.05,{ }^{\star \star \star} p<0.005\right.$, ns- not significant).

efficiencies depending on the deleted protease. The quantity of released DNA by neutrophils in contact with mutant strains at an MOI of 1:1 was significantly lower than the reference strain. In addition, the trend for the observed changes in the mutant strains was different-the amount of released DNA still increased with an increasing MOI. This could suggest that the trigger that inhibited netosis in the wild type fungal cells was not sufficient in the mutant cells lacking protease activity. C. albicans cells deprived of the aspartic proteases Sap9 and Sap10 $(\operatorname{sap} \Delta / \Delta 9 / 10)$, that are GPI-anchored in the cell wall, showed the lowest NET response, reaching only about 25\% of the positive control cells (neutrophils treated with PMA) at an MOI of 1:10. The deletion of Sap1-Sap3 $(\operatorname{sap} \Delta / \Delta 1 / 2 / 3)$ and Sap4-Sap6 $(\operatorname{sap} \Delta / \Delta 4 / 5 / 6)$ resulted in NET generation below $40 \%$ of the positive control levels at an MOI of $1: 10$. However, the lack of Sap8 seemed to have no effect on NET production and at an MOI of 1:10 these mutant cells showed a response similar to that of wild-type cells. Comparing these results with the findings at an MOI of 1:1 it could be concluded that the tested proteases have important roles in netosis activation.

\section{Purified Saps Activate NET Release in a Dose Dependent Manner, Partially via a ROS-Dependent Pathway}

To verify the role of the aspartic proteases in triggering netosis, we treated neutrophils with purified Sap proteins at a wide range of concentrations (0.001-10 $\mathrm{ng} / \mathrm{ml}$; Figure 7). NET release was then measured by the detection of excreted DNA using SytoxGreen, and was also confirmed by microscopic detection of elastase or myeloproxidase to exclude the effects of cell membrane disruption by fungal proteases (data not presented). Moreover, the influence of proteolytic activity on NET production was also tested for the most efficient proteases via the addition of the aspartic protease class inhibitor pepstatin A. No significant proteolytic effects on NET release were observed however (see below).

Our analysis of Sap influence on the netosis yield indicated that NET release is dependent on the stimulant concentration, with the highest effect evident at a protease concentration of $100 \mathrm{pg} / \mathrm{ml}$. We observed from our analysis that Sap3 did not detectably induce NET formation, and that Sap1 and Sap7 induced netosis poorly at a concentration of 1 $\mathrm{ng} / \mathrm{ml}$, only reaching $10-15 \%$ of the positive control level. A slightly higher amount of NET production (up to 40\%) was detected for Sap2, Sap5, and Sap8. However, the highest NET response levels, reaching about $60 \%$ of the positive control, were observed for Sap4 and Sap6 which are produced mainly by the hyphal form of $C$. albicans. The Sap4 concentration that was most efficient for the activation of netosis was 1 $\mathrm{ng} / \mathrm{ml}$ but for Sap6 this activation occurred at a 10 -fold lower protein concentration. The next most efficient Saps for NET production were Sap9 and Sap10, both of which are surfaceanchored enzymes. Significantly high amounts of extracellular DNA were detectable at the Sap9- or Sap10 concentrations of 100 $\mathrm{pg} / \mathrm{ml}$.

To identify the pathway(s) involved in Sap-induced netosis, we compared NET production under protease treatment conditions with or without NADPH oxidase inhibitor (DPI) treatment. Neutrophils were stimulated with each type of Sap at a concentration of $0.1 \mathrm{ng} / \mathrm{ml}$ (Figure 8). In every case, the presence of the NADPH oxidase inhibitor led to a significant decrease in the NET response, suggesting the involvement of a ROS-dependent mechanism in Sap-triggered netosis. However, during treatment of the neutrophils with Sap4 and Sap6 in the presence of DPI, about 25-35\% of the NET production level was preserved. This observation suggested that in case of Sap4 and Sap6 extracellular traps can be produced in part via a ROSindependent pathway. 

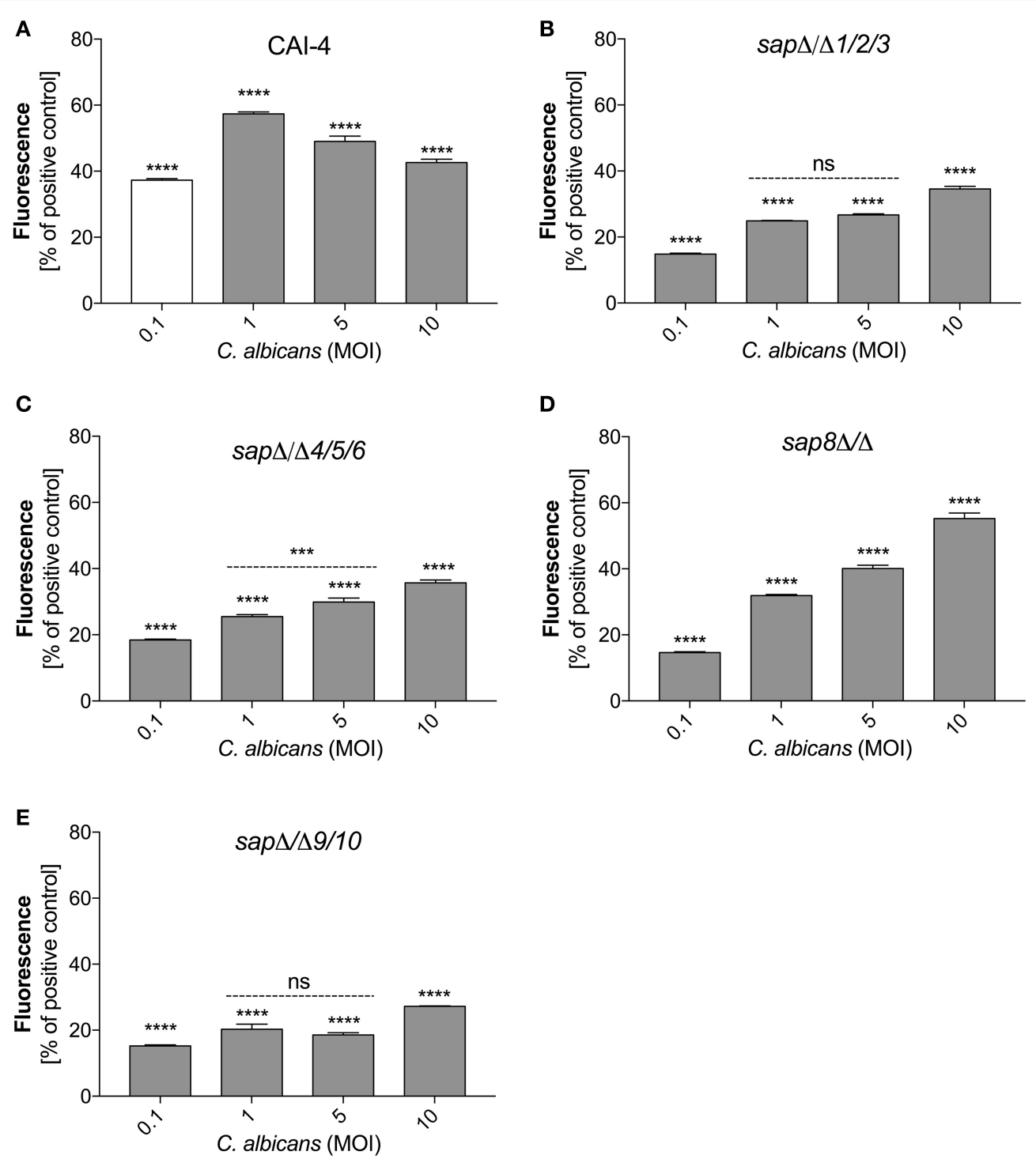

FIGURE 6 | Variable Sap expression regulates NET release. Neutrophils $\left(1.5 \times 10^{6}\right)$ were incubated with cells from the indicated strains of $C$. albicans at different MOI level for $3 \mathrm{~h}$ to induce netosis. Strains with deletions in the $S A P 1 / 2 / 3$ (sap $\Delta / \Delta 1 / 2 / 3)$ (B), $S A P 4 / 5 / 6$ (sap $\Delta / \Delta 4 / 5 / 6)$ (C), $S A P 8$ (sap8 $\Delta / \Delta)$ (D), and $S A P 9 / 10$ $(\operatorname{sap} \Delta / \Delta 9 / 10)$ (E) genes were used, as well as reference cells (CAI-4) (A). The results shown are representative of three independent experiments performed in duplicate. Data are the means \pm SEM and are expressed as percentage ratio of the signal for the tested sample relative to the positive PMA-induced control. Asterisks denote statistical significance relative to the positive control ( ${ }^{\star \star \star} p<0.005$, ${ }^{\star \star \star \star} p<0.001$, ns - not significant).

\section{The Neutrophil CD11b Receptor Is Responsible for the Triggering of Netosis by Saps}

For Saps with the highest NET release potency, we performed a detailed analysis of the responsible neutrophil receptors. We blocked selected receptors with specific antibodies prior to neutrophil treatment with a $1 \mathrm{ng} / \mathrm{ml}$ concentration of Sap4, Sap6, Sap9, or Sap10 (Figure 9). IgG served as a negative control. The Sap4 and Sap6 proteases, secreted mainly by the filamentous form of C. albicans, appeared to activate netosis via the CD11b (Mac-1) receptor, as the antibody block of $\mathrm{CD} 11 \mathrm{~b}$ led to a significant reduction in the extracellular DNA level, to about 50 or $25 \%$ of the control levels, respectively. The CD11a receptor could also be involved in this process, particularly for Sap4, as a NET response reduction of more than $50 \%$ was observed during antibody treatment for this molecule. TLR2 seemed also to play a role in the activation of netosis by Sap4 and Sap6, but at a lower level of potency. Additionally, CD14 may be involved in the triggering of netosis by Sap6.

The cell wall-anchored proteases Sap9 and Sap10 activated netosis mainly via the CD16 and CD18 receptors; a block of these two receptors led to a $50 \%$ NET response reduction. Sap9 was also found to be recognized by the CD11a and CD11b receptors; 


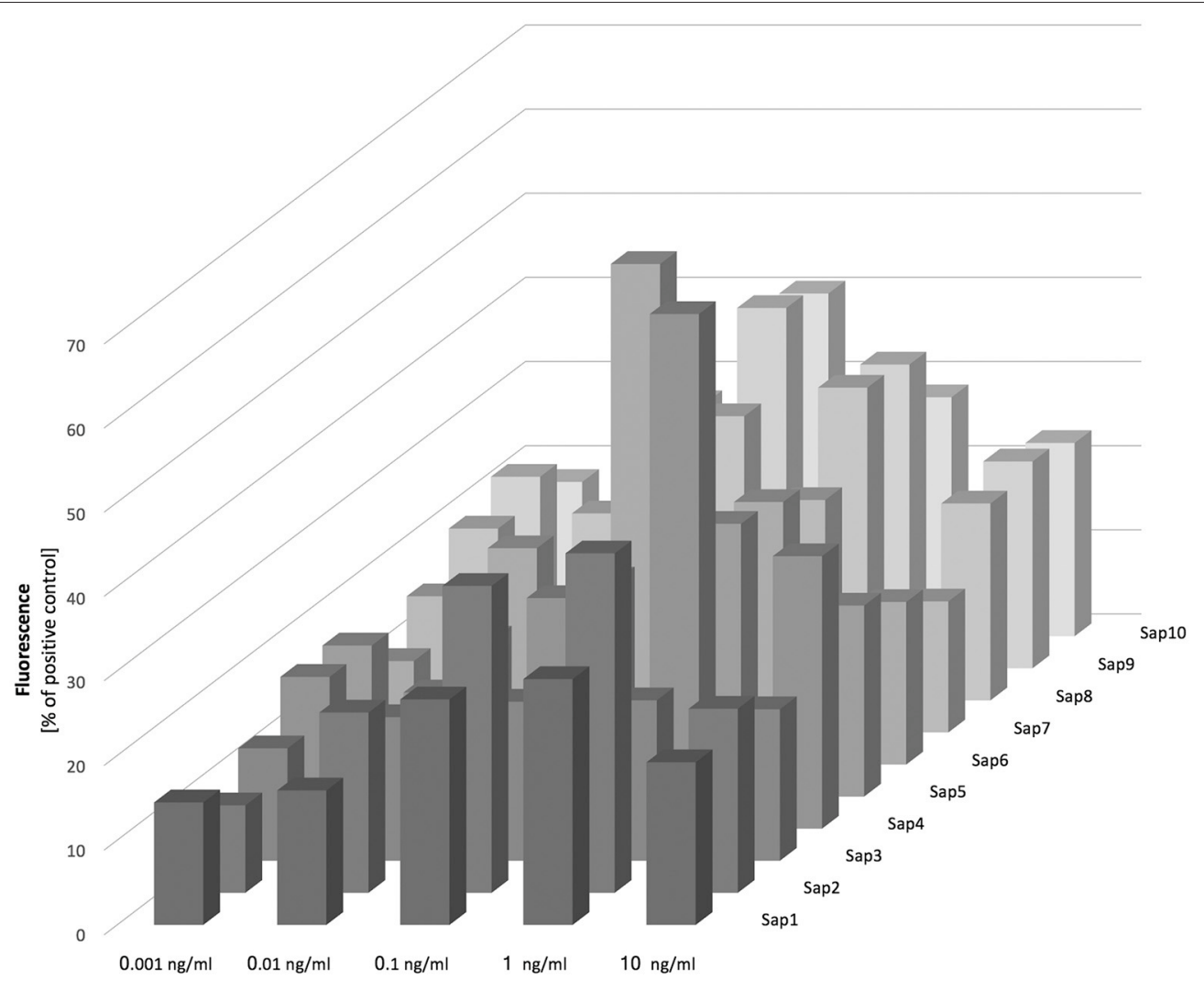

FIGURE 7 | Release of NETs in response to Saps. Neutrophils $\left(2.2 \times 10^{5}\right)$ were incubated for $3 \mathrm{~h}$ with isolated Saps (Sap1-10) within the $0.001-10 \mathrm{ng} / \mathrm{ml}$ concentration range to induce netosis. The amount of released DNA was determined fluorimetrically after SytoxGreen staining, as previously described. Data are the means \pm SEM from two experiments and are expressed as a percentage ratio, as described above.

about 25\% less extracellular DNA was produced by neutrophils treated with the respective antibodies against these receptors. In the case of Sap10, TLR2 and CD11b together with CD14 showed involvement in the NET response at a lower level.

We performed further analysis of the neutrophil receptor CD11b, that mainly mediates NET production under fungal protease treatment conditions, because of its interaction with Sap6, the most efficient protease in terms of netosis. Neutrophils that had settled on the plate or were suspended in the RPMI medium were exposed to fluorescein-labeled Sap6 at increasing protease concentrations for $1 \mathrm{~h}$ (Figure 10). Microscopic analysis of these interactions indicated that Sap6 was mainly localized on the cell surface but was also partially internalized (Figure 10A). Blocking CD11b with a specific antibody led to a significant decrease in the number of Sap6 molecules associated with neutrophils (Figure 10B). Inhibition of the endocytic activity of these cells by treatment with cytochalasin D resulted in a 45$60 \%$ lowering of the interaction with Sap6. Blocking of neutrophil binding and protease internalization completely prevented any Sap6 interaction with neutrophils and further revealed CD11b as a critical factor in this interaction (Figure 10C). Moreover, these Sap6-neutrophil interactions were not influenced by Sap6 proteolytic activity because treatment with a protease inhibitorpepstatin A (Figure 10D) - did not change the results.

\section{Identification of Pathways Involved in Sap6-Activated Netosis}

Specific inhibitors of selected mediators involved in the netosis pathway were used to examine the participation in NET release during contact with the most potent Sap activator, i.e., Sap6. The possible toxicity of each inhibitor toward neutrophils was excluded using the test proposed by Behnen et al. (2014). We identified Src and Syk as the main kinases involved in the induction of netosis during Sap treatment (Figures 11A-C). These mediators cooperate with selected surface receptors mentioned above, such as Dectin-1, CD16, and CD11b (Lowell, 2011; Thomas and Schroder, 2013; Behnen et al., 2014). Inhibition of Src and Syk reduced the amount of released DNA in response to exposure to different Saps by about 50\%. The role of Src was found to be more important for neutrophils treated with Sap9 as compared to Sap4 or Sap6. This is probably because Sap4 and Sap6 trigger mixed netosis pathways. We speculated in this regard that the activation of Syk could transfer the signal downstream to PI3K or ERK1/2.

PI3K participates in the regulation of netosis via NF- $\kappa$ B (DeSouza-Vieira et al., 2016). In our current experiments, PI3K inhibition led to a decrease in NET production in response to each of the tested Saps. However, PI3K seemed to be most important for the induction of netosis by Sap9. Similarly, the 


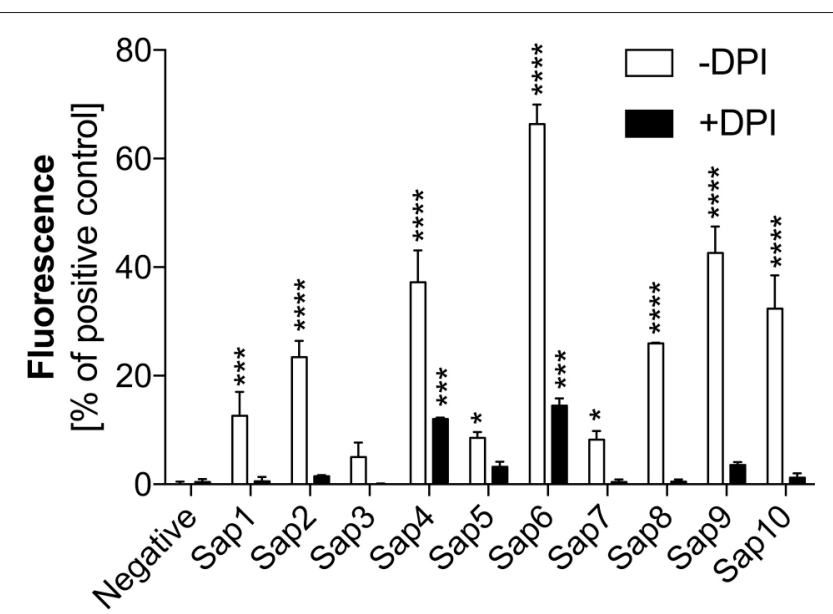

FIGURE 8 | Role of NAPDH oxidase in Sap-induced netosis. Neutrophils (2.2 $\times 10^{5}$ ) were incubated with the indicated Saps at a concentration of $1 \mathrm{ng} / \mathrm{ml}$ for $3 \mathrm{~h}$ to induce netosis. Cells with active NADPH oxidase (-DPI) or with this enzyme inhibited by $5 \mu \mathrm{M} \mathrm{DPI} \mathrm{(+DPI)} \mathrm{treatment} \mathrm{were} \mathrm{used.} \mathrm{The} \mathrm{amount} \mathrm{of}$ released DNA was determined after SytoxGreen staining. Unstimulated neutrophils served as a negative control and 25 nM PMA treatment was assumed to induce a maximal level of NET release. Data are the means \pm SEM from three experiments performed in duplicate. Asterisks denote statistical significance relative to the negative control $\left({ }^{*} p<0.05,{ }^{* \star *} p<0.005\right.$, ${ }^{\star \star \star \star} p<0.001$, ns - not significant).

inhibition of ERK1/2 kinase, which is involved in NET formation connected with ROS induction (Aleman et al., 2016), resulted in the reduced release of DNA. ERK1/2 activation was additionally examined using an ELISA test for phosphorylation of this kinase during neutrophil treatment with Saps (Figure 11D). Sap6 and Sap10 caused a three-fold higher activation of ERK1/2 compared to the unstimulated neutrophils. Lower responses were detected for neutrophils incubated with Sap4 and Sap9, thus correlating with the lower ability of these aspartic proteases to induce netosis.

\section{DISCUSSION}

Neutrophils that encounter the pathogenic forms of C. albicans use many different receptors to sense compounds present at the fungal cell surface, including the main polysaccharide components of the cell wall (glucans and mannans), adhesive surface-bound proteins and Saps. During candidal infection, the structure and properties of the cell surface of this pathogen constantly change, as exemplified by recent finding that the amount and type of cell wall-forming polysaccharides can be dynamically adjusted to make the fungal cells less recognizable by the host immune cells (Hopke et al., 2016). Accordingly, neutrophils use multiple mechanisms to cope with the pathogen attack, including phagocytosis, degranulation, and the most recently described formation of extracellular web-like structures composed of chromatin DNA and granular proteins, i.e., NETs.

In our present study, we have for the first time characterized and compared the efficiency of major classes of compounds, representing the main virulence factors of $C$. albicans that are either embedded in the fugal cell wall or secreted and thus present near the cell surface, that can stimulate neutrophils to release NETs. We propose that NET release (netosis) correlates with the ability of neutrophils to recognize these particles at the moment of infection, and involves the activation of different signaling pathways within neutrophils.

Although, several hypotheses on the causes of NET stimulation during contact with whole C. albicans cells have been proposed previously (Urban et al., 2006; Branzk et al., 2014; Johnson et al., 2016), our current results suggest that the actual number of pathogenic cells is the main regulating factor in the triggering of netosis. As the amount and type of $C$. albicans cells reflect the progress of infection, it seems that netosis is activated at the early stage of host infection, corresponding to an MOI of 1:1 at which stage phagocytosis cannot efficiently reduce the pathogen spread and block the development of infection. On the other hand, we found from our current experiments that an excessive number of pathogenic cells can lead to a decrease in NET formation. This observation is consistent with a previous finding that only large sized pathogen cells can trigger netosis (Branzk et al., 2014). We conclude therefore that the size as well as the number of pathogenic cells, correlating with the stage of infection, can determine the choice of defense mechanism employed by the host against $C$. albicans. Our observations are also consistent with the results obtained by Johnson et al. (2016) who reported that neutrophils showed a lowered NET release in response to the biofilm formed by $C$. albicans when the pathogenic surface in local contact with neutrophil cells was high. This idea is also supported by previous observations of lower efficiency in ROS production during pathogen contact with neutrophils. The coincubation of neutrophils with pathogenic cells at ratio of 1:10 was reported to completely block ROS generation by neutrophils (Wellington et al., 2009). Also, Johnson et al. (2016) showed that neutrophil contact with $C$. albicans biofilm significantly reduced ROS production by these phagocytes. As ROS are necessary for the main pathway of NET formation, a blockade of ROS release by a large number of $C$. albicans cells could be the reason why this causes netosis inhibition.

As the cell wall of $C$. albicans is a thick polysaccharide network composed of a deep layer of chitin, a middle layer of $\beta$-glucans and an external cover comprising mannans, and containing numerous proteins throughout (Chaffin et al., 1998; Karkowska-Kuleta and Kozik, 2015), a crucial question that arose was the identity of the major cell wall components that are most important for the induction of netosis. Among the aforementioned compounds, $\beta$-glucans are the most recognizable by immune cells that induce ROS production and phagocytosis (Figueiredo et al., 2011). The amount of glucans exposed on the surface of $C$. albicans cells has been proven to change during infection whereupon the hyphal form of the pathogen exhibits a lower production of these molecules (Gantner et al., 2003). Moreover, the layer of mannans that covers the deeper layer of glucans prevents recognition of the latter molecules, and results in a decreased immune cell response (Davis et al., 2014). 

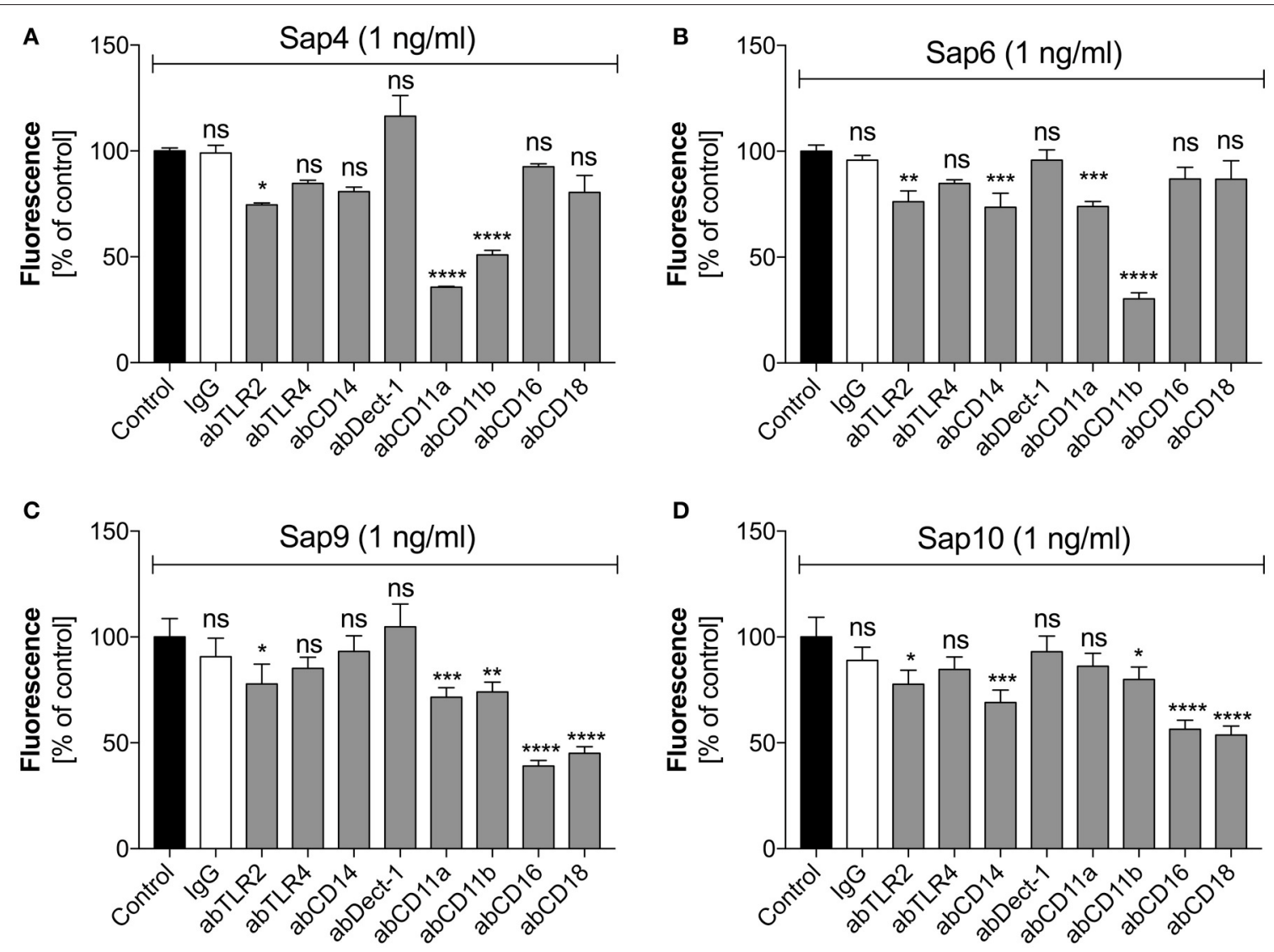

FIGURE 9 | Participation of selected neutrophil receptors in Sap-triggered netosis. Neutrophils $\left(2.2 \times 10^{5}\right)$ were preincubated with antibodies $(\mathbf{a b}, 1 \mu \mathrm{g} / \mathrm{ml})$ against the indicated neutrophil receptors and netosis was then triggered for $3 \mathrm{~h}$ by Sap4 (A), Sap6 (B), Sap9 (C), and Sap10 (D) at an enzyme concentration of $1 \mathrm{ng} / \mathrm{ml}$. lgG antibody was used as an isotype control. The results shown are derived from three independent experiments, performed in duplicate. Data are the means \pm SEM, relative to the untreated control sample. Statistical significance is denoted by asterisks $\left({ }^{\star} p<0.05,{ }^{\star \star} p<0.01,{ }^{\star \star \star} p<0.005,{ }^{{ }^{* \star \star}} p<0.001\right.$, ns - not significant).

Although, $\beta$-glucans are a well-known stimulus of netosis, the signaling pathways involved in this process are still under discussion (Byrd et al., 2013, 2016; Nanì et al., 2015; Johnson et al., 2016). In our present analysis, we observed that glucans activated netosis in a dose-dependent manner, mainly via a ROS-dependent signaling pathway. These results are similar to those obtained by Nanì et al. (2015). On the other hand, Byrd et al. $(2013,2016)$ reported that glucan-induced netosis is ROSindependent and requires a fibronectin base. In contrast to this however, Nanì et al. (2015) recently proposed that fibronectin is not required at the contact surface. Although, our current study findings indicate that NET release upon neutrophil treatment with glucans is dependent on the efficient activity of NADPH oxidase, the possible role also of a ROS-independent mechanism cannot be excluded by our results. Some of the inconsistencies between our present results and those of Nanì et al. or Byrd et al. could be due to the different types of $\beta$-glucans used in each study. An advantage of our current study was the use of $\beta$-glucans isolated from C. albicans cells, in contrast to soluble $\beta$-glucans purified from Saccharomyces cerevisiae that were used by other authors (Byrd et al., 2013, 2016; Nanì et al., 2015). We found that netosis triggered by glucans involved two groups of receptors: Dectin-1 (a C-type lectin receptor) and CR3 receptor (Mac-1; CD11b/CD18). Dectin-1 is known to be one of the major receptors involved in $\beta$-glucan recognition (Brown and Gordon, 2001; Brown et al., 2002, 2003; Li X. et al., 2011) with ROS induction and initiation of phagocytosis as the responses. Mac-1 was also shown to be an important player in $\beta$-glucan recognition by neutrophils (van Bruggen et al., 2009), which is followed by phagocytosis. On the other hand, Byrd et al. (Byrd et al., 2013, 2016) reported that ROS-independent netosis was activated by the CR3 receptor, but not by Dectin-1. Nanì et al. (2015) in turn suggested that NETs released via a ROSdependent pathway engaged the Dectin-1 receptor. They also reported that inhibition of NADPH oxidase did not completely inhibit NET release following contact with $\beta$-glucans. Moreover, another group described the activation of the Mac-1 receptor by glucans as indirect and to be the result of Dectin-1 activation (Li X. et al., 2011). All of these previous insights support our present conclusion that $\beta$-glucans exert a wide influence during netosis and, in combination with the action of other compounds presented on the cell surface, could be a central process by 


\section{A}

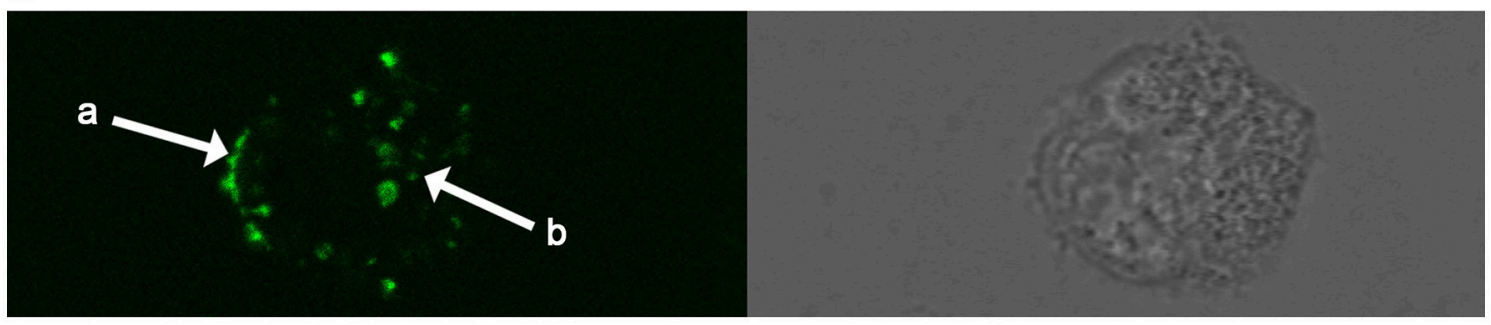

B

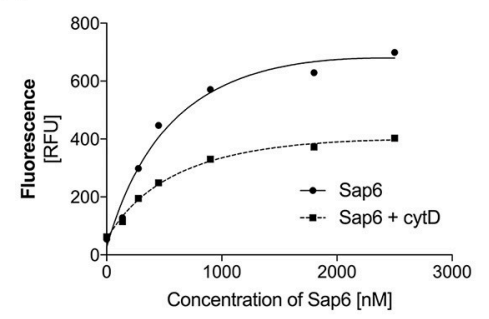

C

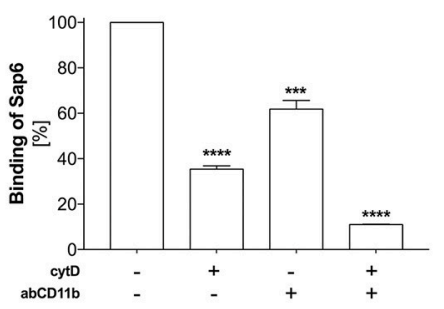

D

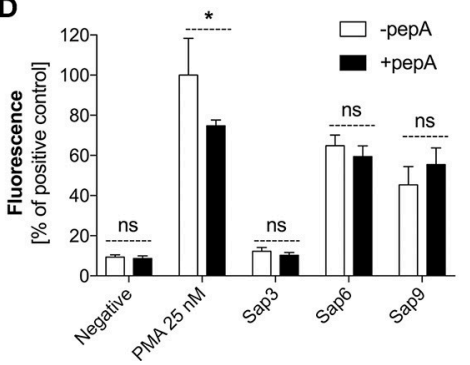

FIGURE 10 | Binding of Sap6 to neutrophils. (A) Neutrophils $\left(2.2 \times 10^{5}\right)$ were incubated for $1 \mathrm{~h}$ with FITC-labeled Sap6 and imaged using fluorescence confocal microscopy. Arrows indicate the localization of the protein on the surface (a) and inside the intracellular compartments (b) of the neutrophils. The left panel represents the fluorescence visualization of Saps that were in contact with the neutrophils. The right panel shows the same cell in transmitted light. Imaging was performed using an immersion lens with a magnification factor of 100x. (B) Interaction of neutrophils with fluorescently labeled Sap6, at concentrations of 0-2.5 $\mu \mathrm{M}$, determined by flow cytometry. The treatments were performed for native cells (Sap6) and for cells with an endocytosis block using $5 \mu$ M cytochalasin D (Sap6 + cytD). Data were collected for 100,000 neutrophils for each experimental point. The results were fitted to the simplest interaction model of one class of binding sites and the estimated curve is presented. The results shown are representative of three independent experiments. (C) Level of fluorescently labeled Sap6 bound to neutrophils determined by microplate assay. Neutrophils in a native state (CytD-, abCD11b-; control sample), with a CD11b receptor block using $1 \mu \mathrm{g} / \mathrm{ml}$ of antibody (CytD-, abCD11b+), with an endocytosis block using $5 \mu \mathrm{M}$ cytochalasin $\mathrm{D}$ (CytD+, abCD11b-), and treated with a combination of these compounds (CytD+, $\mathbf{a b C D 1 1 b + )}$ were used. For fitting of the interaction, the 1:1 interaction model was used. The data are the means \pm SEM of two experiments performed in duplicate and are expressed as a percentage ratio relative to the control sample. (D) Neutrophils $\left(2.2 \times 10^{5}\right)$ were incubated for $3 \mathrm{~h}$ without $(-$ pepA) or with pepstatin $\mathrm{A}$ $(10 \mu \mathrm{M})(+$ pepA) protease inhibitor and with Sap3, Sap6 or Sap9 at concentrations of $1 \mathrm{ng} / \mathrm{ml}$ to induce netosis. Unstimulated neutrophils served as a negative control while neutrophil stimulation with $25 \mathrm{nM}$ PMA was assumed to represent the maximal level of NET release. Data are the means \pm SEM from three independent experiments, performed in duplicate and are expressed as percentage ratio of the tested sample signal relative to the PMA-treated control. Asterisks denote statistical significance $\left({ }^{\star} p<0.05,{ }^{* \star *} p<0.005,{ }^{* \star * *} p<0.001\right.$, ns - not significance) .

which neutrophils ensure an adequate host immune response to C. albicans infection, especially when the mechanism of ROS production is inhibited by this pathogen (Wellington et al., 2009).

Mannans, which are other polysaccharides that comprise the candidal cell wall, are also recognized by neutrophils (Hall and Gow, 2013; Netea et al., 2015). This is important for the host because these polysaccharides often cover the layer of $\beta$ glucans on the $C$. albicans cell surface, rendering it less visible to the host immune system (Bain et al., 2014; Davis et al., 2014). Our present results indicated that neutrophils can detect mannan particles and initiate a NET response to this in a dose-dependent manner. Because the mannan shield appears, in particular, during the transition from the unicellular to hyphal form of C. albicans (Gantner et al., 2005) we hypothesize that the amount of mannans on the cell surface may be an indicator of infection progression, pointing to the need for a diverse set of mechanisms to be utilized by the host response system. This interpretation was further supported by our observation that an excess concentration of mannans or increasing MOI of contacting fungal cells did not produce a NET release. Our results are also consistent with the findings of Johnson et al. who reported that a reduction of C. albicans mannosylation during biofilm formation led to an increased NET formation upon contact between phagocytes and pathogenic cells (Johnson et al., 2016). Moreover, mannan-triggered netosis seems to be independent of ROS generation or, at least, to utilize both mechanisms. This possibility explains why many types of receptors tested in our current analysis seem to be involved in the neutrophil response to mannans. The first group of receptors we tested included the TLR2 and TLR4 neutrophil receptors whose connection with NET release was demonstrated previously (Tada et al., 2002; Netea et al., 2006; Figueiredo et al., 2011). Together with the TLRs, the CD14 receptor also takes part in the identification of fungal compounds and the filamentous form of fungi (Figueiredo et al., 2011). This receptor contributes also to the recognition of mannans (Tada et al., 2002) and, as we documented in our present experiments, is involved in netosis activation. We further described the roles of Dectin-1 and CD11b in NET formation by mannans. Notably, to our knowledge, there has been no information provided previously in the literature about the role of these receptors in mannan recognition. 


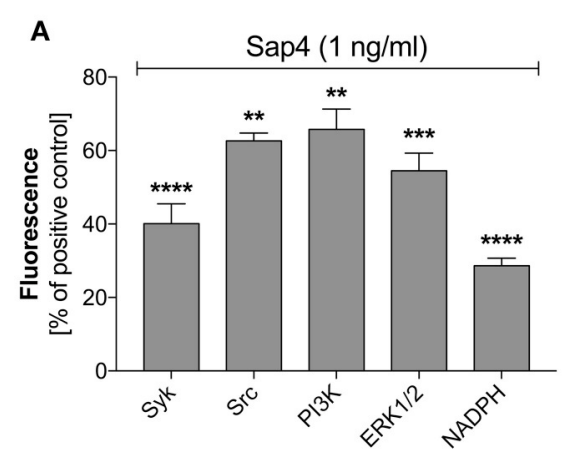

C

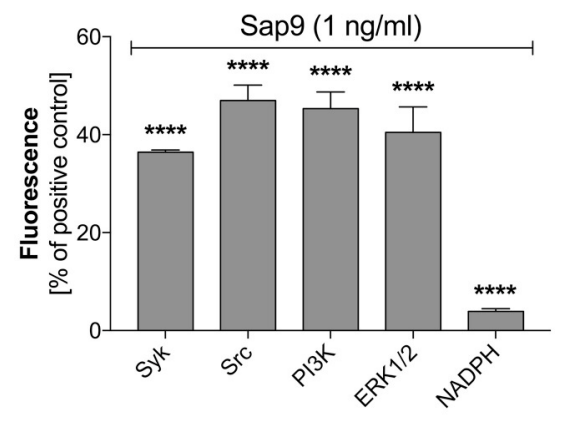

B

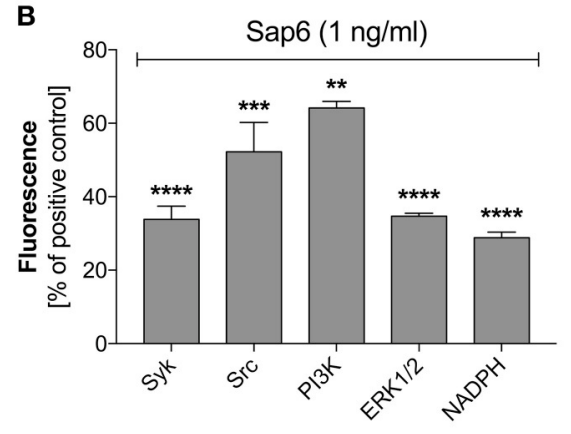

D

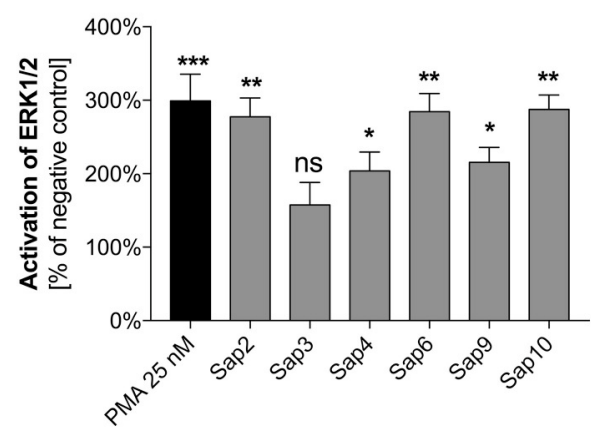

FIGURE 11 | Role of selected signal mediators in Sap-triggered netosis. (A-C) Neutrophils $\left(2.2 \times 10^{5}\right)$ were preincubated with inhibitors of the indicated signaling mediators: Syk-30 $\mu$ M piceatannol, Src-10 $\mu$ M PP2, PI3K-25 $\mu$ M LY29004, ERK-10 $\mu$ M U0126, NADPH oxidase-5 $\mu$ M DPI. These cells were then incubated with Sap4 (A), Sap6 (B), or Sap9 (C) at concentrations of $1 \mathrm{ng} / \mathrm{ml}$ for $3 \mathrm{~h}$ to induce netosis. Neutrophils not treated with inhibitors but stimulated with Saps served as controls. The data are presented as means \pm SEM from three independent experiments (in duplicate) and are expressed as a percentage ratio relative to the PMA-induced control. (D) Lysates were prepared for neutrophils treated with selected Saps at concentration of $1 \mathrm{mg} / \mathrm{ml}$. The levels of phosphorylated and total ERK1/2 were then determined in these cells using an ELISA method. Unstimulated cells were used as a negative control. Data are the ratios of the phosphorylated kinase to total kinase. Data are presented as mean \pm SEM of three independent experiments. Asterisks denote statistical significance relative to the negative control $\left({ }^{\star} p<0.05,{ }^{* \star} p<0.01,{ }^{\star \star *} p<0.005,{ }^{* \star \star *} p<0.001\right.$, ns- not significant).

The C. albicans cell wall also contains proteinaceous compounds, the most important group of which comprises the adhesins that are capable of binding to many host proteins and/or become involved directly in adhesion processes. A representative of this group evaluated in our current study was Als3, a prominent adhesin often overexpressed and detected in candidal infections (Liu and Filler, 2011). However, we did not find any evidence for its involvement in netosis. In contrast, our current results showed that neutrophils released NETs upon contact with enolase-the cytosolic enzyme involved in the glycolysis pathway and also known to be exposed on the cell surface of numerous pathogens where it can "moonlight" as an adhesin that is important for pathogen cell adherence to the host tissues (Karkowska-Kuleta and Kozik, 2014). Similar NET-inducing effects were observed previously for $\alpha$-enolase from Streptococcus pneumoniae (Mori et al., 2012). Nevertheless, we found that $C$. albicans enolase seemed be a far less potent activator of netosis as compared to the polysaccharides mentioned above, and to only do so within a relatively narrow concentration range. However, a role of enolase in netosis cannot be excluded, particularly during the formation of biofilms in which this protein has been found to cover C. albicans cells.
Another important group of C. albicans virulence factors is the family of 10 Saps. These enzymes are expressed at various combinations and at different places and stages of infection (Naglik et al., 2008; Pietrella et al., 2010) and have been proven to support the invasion of $C$. albicans cells into host tissues (Staniszewska et al., 2012). All of the C. albicans Saps are released as soluble forms into the surrounding medium except for Sap9 and Sap10 which are covalently attached to the fungal cell wall. Neutrophils can identify Saps as chemotactic agents that induce further inflammation (Naglik et al., 2003a; Pietrella et al., 2013; Pericolini et al., 2015; Gabrielli et al., 2016). The most convincing results in our current analysis that indicated the significance of Saps for netosis activation came from the comparison of NET release during the contact of neutrophils with wild and Sapknockout mutant strains of $C$. albicans. In this analysis, the elimination of dedicated proteases resulted in a changed netosis response in correlation with an increased MOI of contacting cells (Figure 6). These observations were consistent with the results from experiments performed with purified enzymes. For all 10 Saps analyzed in our current experiments, we compared the effect of NET release at different enzyme concentrations. However, it must be noted that a knockout of one enzyme from the Sap 
TABLE 2 | Summary of netosis induction by virulence factors at the cell surface of C. albicans.

\begin{tabular}{|c|c|c|c|}
\hline $\begin{array}{l}\text { Component of } \\
\text { C. albicans }\end{array}$ & $\begin{array}{l}\text { Induction of } \\
\text { netosis }\end{array}$ & Pathway & Involved receptors \\
\hline$\beta$-Glucan & Yes & ROS-dependent & Dectin-1, Mac-1 \\
\hline Mannan & Yes & Mixed* & $\begin{array}{l}\text { Dectin-1(?), CD14, Mac-1, } \\
\text { TLR2, TLR4 }\end{array}$ \\
\hline $\begin{array}{l}\text { Moonlight proteins } \\
\text { (enolase) }\end{array}$ & Yes (poorly) & - & - \\
\hline Adhesin (Als3) & No & - & - \\
\hline Sap1 & Yes & ROS-dependent & $\sim$ \\
\hline Sap2 & Yes & ROS-dependent & $\sim$ \\
\hline Sap3 & No & - & $\sim$ \\
\hline Sap4 & Yes & Mixed $^{*}$ & CD11a, CD11b \\
\hline Sap5 & No (poorly) & - & $\sim$ \\
\hline Sap6 & Yes & Mixed ${ }^{*}$ & $\begin{array}{l}\text { CD11b, CD11a, CD14, } \\
\text { TLR2 }\end{array}$ \\
\hline Sap7 & No (poorly) & & $\sim$ \\
\hline Sap8 & Yes & ROS-dependent & $\sim$ \\
\hline Sap9 & Yes & ROS-dependent & $\begin{array}{l}\text { CD16, CD18, CD11a, } \\
\text { CD11b }\end{array}$ \\
\hline Sap10 & Yes & ROS-dependent & CD16, CD18, CD14 \\
\hline
\end{tabular}

${ }^{\star} R O S$-dependent and ROS-independent; , not analyzed.

family can be compensated for by the increased expression of another Sap to rescue virulence deficiencies (Naglik et al., 2003a, 2004, 2008; Albrecht et al., 2006). The strongest response was previously observed for Sap4 and Sap6, which are dominant for the filamentous form of C. albicans (Hube et al., 1994; Naglik et al., 2003a) which is more virulent than the unicellular yeastlike form and induces a stronger NET response upon contact with neutrophils. The importance of these Saps in C. albicans infection is not only due to their proteolytic properties, but also to their role in fungal cell integrity and adherence (Naglik et al., 2003a; Buu and Chen, 2013; Kumar et al., 2015).

The markedly lower response of neutrophils to Sap1-Sap3 treatments corresponded to their predominant expression in the yeast-like form of C. albicans (Naglik, 2014) which is a less active inducer of netosis. The lowest potency found for Sap7 in terms of NET induction could be explained by its lowest sequence similarity to other members of Sap family and its different structural properties (Aoki et al., 2012). Moreover, the SAP7 gene is often not expressed during infection and its role as a virulence factor has not been well established (Naglik et al., 2003b, 2008; Naglik, 2014). The response of neutrophils to contact with Sap8 and their recognition of the mutant C. albicans strain containing a Sap8 deletion suggested possible neutrophil activation by this Sap to form NETs but the mechanisms by which Sap8 may contribute to human infection in general remain unclear (Carvalho-Pereira et al., 2015).

Sap9 and Sap10 are closely related and are linked via a GPI anchor to the Candida cell wall (Monod et al., 1998; Schild et al., 2011). These enzymes represent the second group of proteases that strongly support netosis. This newly presented role of these Saps from our current analysis broadens our understanding of their ability to participate in $C$. albicans infection, and supplements their previously known roles in cell growth, cell surface integrity and adhesion (Naglik et al., 2008; Nailis et al., 2010; Schild et al., 2011), and biofilm formation (Dutton et al., 2016).

Our attempts to determine the mechanisms involved in the activation of netosis during neutrophil contact with the most effective netosis-inducing Saps revealed some dual actions. The activity of NADPH oxidase and, hence, ROS production appeared to be important for Sap-induced netosis, mainly upon the contact of neutrophils with Sap1, Sap2, Sap8, Sap9, and Sap10. On the other hand, neutrophils treated with an NADPH oxidase inhibitor and with Sap4 and Sap6 still released NETs, but the amount of DNA was significantly reduced. This suggests the possibility of a selection between ROS-dependent and ROSindependent mechanisms in this case. The activation of ROSindependent processes as an alternative pathway could be a mode of host protection against immune response inactivation by ROS during fungal or bacterial infection (Wellington et al., 2009). However, the role of this dual mechanistic response during netosis triggering still remains unclear. Further analysis of involved receptors and concomitant activation of the corresponding signaling pathways could shed more light on this issue. However, it is worth noting that closely interlinked signaling events cannot be assigned to the action of a single receptor (Duggan et al., 2015).

Sap4 and Sap6, which can activate netosis by ROS-dependent and ROS-independent mechanisms, were recognized during this process mainly by CD11b (Mac-1) and CD11a (LFA-1) receptors. Moreover, Sap6 was also found to stimulate the CD14 receptor. Mac-1 participates in many different types of neutrophil responses, including phagocytosis, internalization and netosis (Whitlock et al., 2000; Behnen et al., 2014). It also causes the downstream activation of the Src/Syk kinase family (Whitlock et al., 2000; Behnen et al., 2014). In turn, the CD14 receptor can serve as a co-receptor for TLR4 (Zanoni et al., 2011) and CD16 (FcyRIIIB) (Detmers et al., 1995). As we have shown from our current findings, the activation of netosis by Sap9 and Sap10 occurs through the action of CD16 (Fc $\gamma$ RIIIB) and CD18 receptors. The participation of CD16 in the recognition of immune complexes, as well as in the induction of netosis, has been documented previously (Aleman et al., 2016). Moreover, CD16 can cooperate with the Mac-1 receptor (Zhou and Brown, 1994) and could be an important factor in the mixed mechanism activation of netosis. Additionally, a weaker involvement of the CD11a and CD11b receptors in Sap9 recognition and the CD14 receptor in Sap 10 recognition were also observed in our experiments.

The participation of a number of cooperating receptors in the identification of the Saps leads to netosis activation through the same signal-transducers. We examined the role of four signal mediators, Src, Syk, PI3K, and ERK, in this regard. The role of Src/Syk kinases in NET formation was confirmed previously (Behnen et al., 2014; Nanì et al., 2015; Aleman et al., 2016), pointing to the Src family kinases as the key signaling mediators activated by the CD11b receptor as well as the CD16 receptor (Lowell, 2011; Behnen et al., 2014), with further activation of Syk 


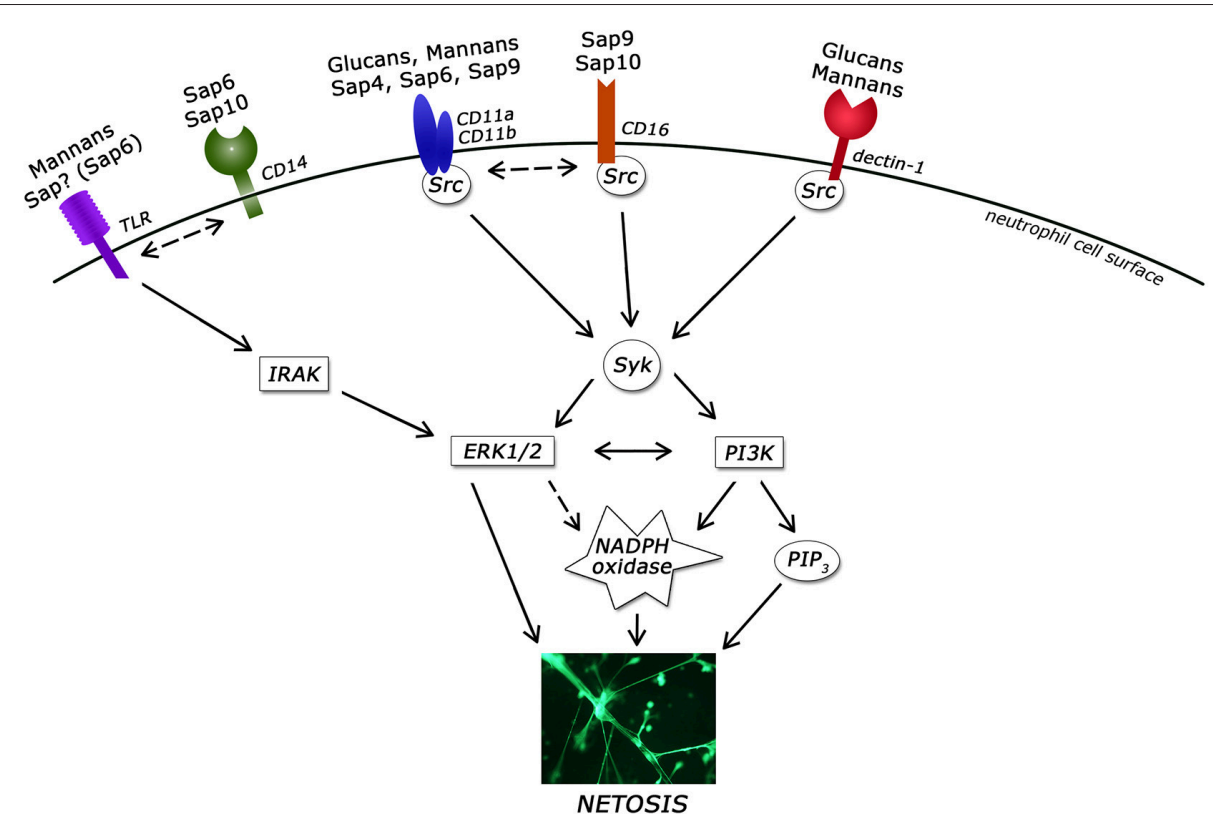

FIGURE 12 | Involvement of neutrophil receptors and signaling pathways in NET activation by the main virulence factors of Candida albicans. ERK1/2, extracellular signal-regulated kinases; IRAK, Interleukin-1 receptor-associated kinases; Src, Src kinase family; Syk, spleen tyrosine kinase; PI3K, extracellular signal-regulated kinases; $\mathrm{PIP}_{3}$, phosphatidylinositol $(3,4,5)$-trisphosphate; PKC, protein kinase C; TLR, Toll-like receptor.

and downstream signal transduction via the activation of PI3K (Lowell, 2011) and ERK1/2 (Whitlock et al., 2000; Behnen et al., 2014). The identity of the receptors involved in the neutrophil response to Saps suggests that the Src/Syk kinases also play an important role in netosis via activation by $C$. albicans virulence factors. Indeed, our current finding of a reduced NET response during the inhibition of Src or Syk in neutrophils treated with Saps has confirmed that hypothesis.

It must be noted that the role of PI3K in netosis is still unclear. Aleman et al. suggested previously that NET induction by CD16 did not require PI3K activation (Aleman et al., 2016) but Behnen et al. described an important role of this mediator in netosis (Behnen et al., 2014). Moreover, PI3K activation in parasite-induced NET formation was confirmed in another study (DeSouza-Vieira et al., 2016). PI3K generates phosphatidylinositol $(3,4,5)$-trisphosphate $\left(\mathrm{PIP}_{3}\right)$ which regulates the transcription factor NF-kB (Ward et al., 2004), promoting proinflammatory responses and NET formation (Lapponi et al., 2013). Our current results indicate however, that PI3K inhibition led to only a partial reduction in extracellular DNA release by neutrophils in response to Saps.

Another important signal mediator, ERK1/2, has also been proposed to be involved in NET induction (Hakkim et al., 2011; Behnen et al., 2014; Aleman et al., 2016; DeSouza-Vieira et al., 2016) but its precise role in netosis is still unclear. Some studies have reported that the upstream activation of ERK1/2 is essential for ROS formation (Hakkim et al., 2011) but others have found that ERK1/2 activation was downstream-regulated by the activity of NADPH oxidase (Keshari et al., 2012). In our present models of neutrophil treatment with Saps, we confirmed the contribution of ERK1/2 to the NET release process. It is worth noting also in this regard that the activation of ERK1/2 by Syk kinase involves TLR receptor mediation, which activates ERK1/2 via the IRAK family of proteins (Futosi et al., 2013). Moreover, IRAK kinases may activate the NF-kB signaling pathway, which could be particularly important for Sap6 and Sap10. These two Saps seem to induce netosis also via the CD14 receptor, a co-receptor for the TLRs.

In our more detailed analysis of the Sap6 interaction with neutrophils, as the most potent NET-generating protease, we observed that the Mac-1 receptor could interact directly with Sap6 at the surface of the neutrophils. However, a Mac-1 block did not completely reduce this interaction, suggesting that the interplay between Sap6 and neutrophils is more complex and may involve other integrins. This finding directed our attention to the surface-exposed integrin-binding motif (RGD) that is present only in Sap 4 (a single RGD motif), Sap5 (an RGDKGD motif), and Sap6 (two sequential RGDRGD integrinbinding motives) and is involved in interactions with integrin on epithelial cells (Wu et al., 2013). No other Saps contain this motif which may partially explain the strongest and ROSindependent neutrophil response to Sap6. It is also worth noting that variations in the RGD motif affect the binding affinity to a particular integrin molecule (Scarborough et al., 1993). Hence, the divergence of this motif between Sap5 and Sap6 could underlie the differences between these proteases in triggering NET release. Moreover, our current results also strongly suggest a very tight binding between neutrophil integrin and hyphal Saps. Similar interactions were also reported previously for fungal cell aggregation and virulence (Kumar et al., 2015). 
Further effects of Sap6 interaction with neutrophils, resulting in NET production, seem to be connected with its internalization, a well identified process for the activation of the inflammasome in monocytes where internalization of Sap6 via clathrin-dependent mechanism is required (Pietrella et al., 2013) and is connected with ROS production, or for the induction of epithelial cell apoptosis via a "Trojan horse" mechanism (Wu et al., 2013). The internalization of Sap6 by neutrophils may be vital for a fast response to $C$. albicans invasion, probably through a ROS-independent netosis pathway. However, this issue requires further studies to elucidate the pathways more precisely.

The information in this study concerning NET release following neutrophil contact with the known C. albicans virulence factors are summarized in Table 2 and presented in Figure 12.

\section{AUTHOR CONTRIBUTIONS}

Conceived and designed the experiments: $M R$ and MZ. Performed the experiments: MZ, OB, JK, and KS. Preparation of

\section{REFERENCES}

Albrecht, A., Felk, A., Pichova, I., Naglik, J. R., Schaller, M., de Groot, P., et al. (2006). Glycosylphosphatidylinositol-anchored proteases of Candida albicans target proteins necessary for both cellular processes and host-pathogen interactions. J. Biol. Chem. 281, 688-694. doi: 10.1074/jbc.M509297200

Aleman, O. R., Mora, N., Cortes-Vieyra, R., Uribe-Querol, E., and Rosales, C. (2016). Differential use of human neutrophil Fc receptors for inducing neutrophil extracellular trap formation. J. Immunol. Res. 2016:2908034. doi: $10.1155 / 2016 / 2908034$

Aoki, W., Kitahara, N., Miura, N., Morisaka, H., Yamamoto, Y., Kuroda, K., et al. (2011). Comprehensive characterization of secreted aspartic proteases encoded by a virulence gene family in Candida albicans. J. Biochem. 150, 431-438. doi: $10.1093 / \mathrm{jb} / \mathrm{mvr} 073$

Aoki, W., Kitahara, N., Miura, N., Morisaka, H., Yamamoto, Y., Kuroda, K., et al. (2012). Candida albicans possesses Sap7 as a pepstatin A-insensitive secreted aspartic protease. PLoS ONE 7:e32513. doi: 10.1371/journal.pone.0032513

Bain, J. M., Louw, J., Lewis, L. E., Okai, B., Walls, C. A., Ballou, E. R., et al. (2014). Candida albicans hypha formation and mannan masking of $\beta$-glucan inhibit macrophage phagosome maturation. MBio 5:e01874. doi: $10.1128 / \mathrm{mBio} .01874-14$

Behnen, M., Leschczyk, C., Möller, S., Batel, T., Klinger, M., Solbach, W., et al. (2014). Immobilized immune complexes induce neutrophil extracellular trap release by human neutrophil granulocytes via Fc $\gamma$ RIIIB and Mac-1. J. Immunol. 193, 1954-1965. doi: 10.4049/jimmunol.1400478

Bochenska, O., Rapala-Kozik, M., Wolak, N., Aoki, W., Ueda, M., and Kozik, A. (2016). The action of ten secreted aspartic proteases of pathogenic yeast Candida albicans on major human salivary antimicrobial peptide, histatin 5 . Acta Biochim. Pol. 63, 403-410. doi: 10.18388/abp.2016_1318

Borg-von Zepelin, M., Beggah, S., Boggian, K., Sanglard, D., and Monod, M. (1998). The expression of the secreted aspartyl proteinases Sap4 to Sap6 from Candida albicans in murine macrophages. Mol. Microbiol. 28, 543-554. doi: 10.1046/j.1365-2958.1998.00815.x

Bradford, M. (1976). A rapid and sensitive method for the quantitation of microgram quantities of protein utilizing the principle of proteindye binding. Anal. Biochem. 72, 248-254. doi: 10.1016/0003-2697(76) 90527-3

Branzk, N., Lubojemska, A., Hardison, S. E., Wang, Q., Gutierrez, M. G., Brown, G. D., et al. (2014). Neutrophils sense microbe size and selectively release neutrophil extracellular traps in response to large pathogens. Nat. Immunol. 15, 1-11. doi: 10.1038/ni.2987 plasmids: WA and MU. Analyzed the data and wrote the paper: MZ and MR. Revised it critically: AK.

\section{FUNDING}

This work was supported in part by the National Science Centre, Poland (grant No. 2012/05/B/NZ1/00003 awarded to MR). The Faculty of Biochemistry, Biophysics, and Biotechnology of the Jagiellonian University in Krakow is a beneficiary of structural funds from the European Union (grant no. POIG.02.01.0012-064/08, "Molecular Biotechnology for Health") and a partner of the Leading National Research Center (KNOW) supported by the Ministry of Science and Higher Education, Poland.

\section{ACKNOWLEDGMENTS}

We thank Dr. Bernhard Hube for providing C. albicans mutant strains and Dr. Jerzy Dobrucki for providing access to the confocal microscope.

Branzk, N., and Papayannopoulos, V. (2013). Molecular mechanisms regulating NETosis in infection and disease. Semin. Immunopathol. 35, 513-530. doi: 10.1007/s00281-013-0384-6

Brinkmann, V., Reichard, U., Goosmann, C., Fauler, B., Uhlemann, Y., Weiss, D. S., et al. (2004). Neutrophil extracellular traps kill bacteria. Science 303, 1532-1535. doi: 10.1126/science.1092385

Brinkmann, V., and Zychlinsky, A. (2012). Neutrophil extracellular traps: is immunity the second function of chromatin? J. Cell Biol. 198, 773-783. doi: $10.1083 /$ jcb. 201203170

Brown, G. D., and Gordon, S. (2001). Immune recognition. A new receptor for beta-glucans. Nature 413, 36-37. doi: 10.1038/35092620

Brown, G. D., Herre, J., Williams, D. L., Willment, J. A., Marshall, A. S. J., and Gordon, S. (2003). Dectin-1 mediates the biological effects of beta-glucans. J. Exp. Med. 197, 1119-1124. doi: 10.1084/jem.20021890

Brown, G. D., Taylor, P. R., Reid, D. M., Willment, J. A., Williams, D. L., MartinezPomares, L., et al. (2002). Dectin-1 is a major-glucan receptor on macrophages. J. Exp. Med. 196, 407-412. doi: 10.1084/jem.20020470

Buu, L.-M., and Chen, Y.-C. (2013). Sap6, a secreted aspartyl proteinase, participates in maintenance the cell surface integrity of Candida albicans. J. Biomed. Sci. 20:101. doi: 10.1186/1423-0127-20-101

Byrd, A. S., O'Brien, X. M., Johnson, C. M., Lavigne, L. M., and Reichner, J. S. (2013). An extracellular matrix-based mechanism of rapid neutrophil extracellular trap formation in response to Candida albicans. J. Immunol. 190, 4136-4148. doi: 10.4049/jimmunol.1202671

Byrd, A. S., O’Brien, X. M., Laforce-Nesbitt, S. S., Parisi, V. E., Hirakawa, M. P., Bliss, J. M., et al. (2016). NETosis in neonates: evidence of a reactive oxygen species-independent pathway in response to fungal challenge. J. Infect. Dis. 213, 634-639. doi: 10.1093/infdis/jiv435

Calderone, R. A., and Fonzi, W. A. (2001). Virulence factors of Candida albicans. Trends Microbiol. 9, 327-335. doi: 10.1016/S0966-842X(01)02094-7

Carvalho-Pereira, J., Vaz, C., Carneiro, C., Pais, C. C., and Sampaio, P. (2015). Genetic variability of Candida albicans Sap8 propeptide in isolates from different types of infection. Biomed. Res. Int. 2015:148343. doi: 10.1155/2015/148343

Chaffin, W. L., López-Ribot, J. L., Casanova, M., Gozalbo, D., and Martínez, J. P. (1998). Cell wall and secreted proteins of Candida albicans: identification, function, and expression. Microbiol. Mol. Biol. Rev. 62, 130-180.

Collette, J. R., and Lorenz, M. C. (2011). Mechanisms of immune evasion in fungal pathogens. Curr. Opin. Microbiol. 14, 668-675. doi: 10.1016/j.mib.2011.09.007

Crowe, J. D., Sievwright, I. K., Auld, G. C., Moore, N. R., Gow, N. A. R., and Booth, N. A. (2003). Candida albicans binds human plasminogen: 
identification of eight plasminogen-binding proteins. Mol. Microbiol. 47, 1637-1651. doi: 10.1046/j.1365-2958.2003.03390.x

Davis, S. E., Hopke, A., Minkin, S. C., Montedonico, A. E., Wheeler, R. T., and Reynolds, T. B. (2014). Masking of $\beta(1-3)$-glucan in the cell wall of Candida albicans from detection by innate immune cells depends on phosphatidylserine. Infect. Immun. 82, 4405-4413. doi: 10.1128/IAI.01612-14

DeSouza-Vieira, T., Guimarães-Costa, A., Rochael, N. C., Lira, M. N., Nascimento, M. T., Lima-Gomez, P. S., et al. (2016). Neutrophil extracellular traps release induced by Leishmania: role of PI3K $\gamma$, ERK, PI3K $\sigma, \mathrm{PKC}$, and $\left[\mathrm{Ca}^{2+}\right]$. J. Leukoc. Biol. 100, 1-9. doi: 10.1189/jlb.4A0615-261RR

Detmers, P. A., Zhou, D., Powell, D., Lichenstein, H., Kelley, M., and Pironkova, R. (1995). Endotoxin receptors (CD14) are found with CD16 (Fc gamma RIII) in an intracellular compartment of neutrophils that contains alkaline phosphatase. J. Immunol. 155, 2085-2095.

Dubois, M., Gilles, K., Hamilton, J., Rebers, P., and Smith, F. (1951). A colorimetric method for the determination of sugars. Nature 168:167. doi: 10.1038/168167a0

Duggan, S., Leonhardt, I., Hünniger, K., and Kurzai, O. (2015). Host response to Candida albicans bloodstream infection and sepsis. Virulence 6, 316-326. doi: 10.4161/21505594.2014.988096

Dutton, L. C., Jenkinson, H. F., Lamont, R. J., and Nobbs, A. H. (2016). Role of Candida albicans secreted aspartyl protease Sap9 in interkingdom biofilm formation. Pathog. Dis. 74:ftw005. doi: 10.1093/femspd/ftw005

Figueiredo, R. T., Carneiro, L. A. M., and Bozza, M. T. (2011). Fungal surface and innate immune recognition of filamentous fungi. Front. Microbiol. 2:248. doi: 10.3389/fmicb.2011.00248

Fonzi, W. A., and Irwin, M. Y. (1993). Isogenic strain construction and gene mapping in Candida albicans. Genetics 134, 717-728.

Futosi, K., Fodor, S., and Mócsai, A. (2013). Neutrophil cell surface receptors and their intracellular signal transduction pathways. Int. Immunopharmacol. 17, 638-650. doi: 10.1016/j.intimp.2013.06.034

Gabrielli, E., Sabbatini, S., Roselletti, E., Kasper, L., Perito, S., Hube, B., et al. (2016). In vivo induction of neutrophil chemotaxis by secretory aspartyl proteinases of Candida albicans. Virulence 7, 819-825. doi: 10.1080/21505594.2016.11 84385

Gantner, B. N., Simmons, R. M., Canavera, S. J., Akira, S., and Underhill, D. M. (2003). Collaborative induction of inflammatory responses by dectin-1 and Toll-like receptor 2. J. Exp. Med. 197, 1107-1117. doi: 10.1084/jem.200 21787

Gantner, B. N., Simmons, R. M., and Underhill, D. M. (2005). Dectin-1 mediates macrophage recognition of Candida albicans yeast but not filaments. EMBO J. 24, 1277-1286. doi: 10.1038/sj.emboj.7600594

Gazendam, R. P., Van Hamme, J. L., Tool, A. T., van Houdt, M., Verkuijlen, P. J., Herbst, M., et al. (2014). Two independent killing mechanisms of Candida albicans by human neutrophils: evidence from innate immunity defects. Blood 124, 590-597. doi: 10.1182/blood-2014-01-551473

Gropp, K., Schild, L., Schindler, S., Hube, B., Zipfel, P. F., and Skerka, C. (2009). The yeast Candida albicans evades human complement attack by secretion of aspartic proteases. Mol. Immunol. 47, 465-475. doi: 10.1016/j.molimm.2009.08.019

Hakkim, A., Fuchs, T. A., Martinez, N. E., Hess, S., Prinz, H., Zychlinsky, A., et al. (2011). Activation of the Raf-MEK-ERK pathway is required for neutrophil extracellular trap formation. Nat. Chem. Biol. 7, 75-77. doi: 10.1038/nchembio. 496

Hall, R. A., and Gow, N. A. R. (2013). Mannosylation in Candida albicans: role in cell wall function and immune recognition. Mol. Microbiol. 90, 1147-1161. doi: $10.1111 / \mathrm{mmi} .12426$

Hopke, A., Nicke, N., Hidu, E. E., Degani, G., Popolo, L., and Wheeler, R. T. (2016). Neutrophil attack triggers extracellular trap-dependent candida cell wall remodeling and altered immune recognition. PLoS Pathog. 12:e1005644. doi: 10.1371/journal.ppat.1005644

Hornbach, A., Heyken, A., Schild, L., Hube, B., Löffler, J., and Kurzai, O. (2009). The glycosylphosphatidylinositol-anchored protease Sap9 modulates the interaction of Candida albicans with human neutrophils. Infect. Immun. 77, 5216-5224. doi: 10.1128/IAI.00723-09

Hube, B., Monod, M., Schofield, D. A., Brown, A. J. P., and Gow, N. A. R. (1994). Expression of seven members of the gene family encoding secretory aspartyl proteinases in Candida albicans. Mol. Microbiol. 14, 87-99. doi: 10.1111/j.1365-2958.1994.tb01269.x
Ibrahim, A. S., Filler, S. G., Sanglard, D., Edwards, J. E., and Hube, B. (1998). Secreted aspartyl proteinases and interactions of Candida albicans with human endothelial cells. Infect. Immun. 66, 3003-3005.

Johnson, C. J., Cabezas-Olcoz, J., Kernien, J. F., Wang, S. X., Beebe, D. J., Huttenlocher, A., et al. (2016). The extracellular matrix of Candida albicans biofilms impairs formation of Neutrophil Extracellular Traps. PLOS Pathog. 12:e1005884. doi: 10.1371/journal.ppat.1005884

Karkowska-Kuleta, J., and Kozik, A. (2014). Moonlighting proteins as virulence factors of pathogenic fungi, parasitic protozoa and multicellular parasites. Mol. Oral Microbiol. 29, 270-283. doi: 10.1111/omi.12078

Karkowska-Kuleta, J., and Kozik, A. (2015). Cell wall proteome of pathogenic fungi. Acta Biochim. Pol. 62, 339-351. doi: 10.18388/abp.2015_1032

Keshari, R. S., Verma, A., Barthwal, M. K., and Dikshit, M. (2012). Reactive oxygen species-induced activation of ERK and p38 MAPK mediates PMAinduced NETs release from human neutrophils. J. Cell. Biochem. 114, 532-540. doi: $10.1002 /$ jcb. 24391

Kocourek, J., and Ballou, C. E. (1969). Method for fingerprinting yeast cell wall mannans. J. Bacteriol. 100, 1175-1181.

Kozik, A., Gogol, M., Bochenska, O., Karkowska-Kuleta, J., Wolak, N., Kamysz, W., et al. (2015). Kinin release from human kininogen by 10 aspartic proteases produced by pathogenic yeast Candida albicans. BMC Microbiol. 15:60. doi: 10.1186/s12866-015-0394-8

Kumar, R., Saraswat, D., Tati, S., and Edgerton, M. (2015). Novel aggregation properties of Candida albicans secreted aspartyl proteinase sap6 mediate virulence in oral Candidiasis. Infect. Immun. 83, 2614-2626. doi: 10.1128/IAI.00282-15

Lagunes, L., and Rello, J. (2016). Invasive candidiasis: from mycobiome to infection, therapy, and prevention. Eur. J. Clin. Microbiol. Infect. Dis. 35, 1221-1226. doi: 10.1007/s10096-016-2658-0

Lapponi, M. J., Carestia, A., Landoni, V. I., Rivadeneyra, L., Etulain, J., Negrotto, S., et al. (2013). Regulation of neutrophil extracellular trap formation by anti-inflammatory drugs. J. Pharmacol. Exp. Ther. 345, 430-437. doi: 10.1124/jpet.112.202879

Li, Wq., Hu, Xc., Zhang, X., Ge, Y., Zhao, S., Hu, Y., et al. (2011). Immunisation with the glycolytic enzyme enolase confers effective protection against Candida albicans infection in mice. Vaccine 29, 5526-5533. doi: 10.1016/j.vaccine.2011.05.030

Li, X., Utomo, A., Cullere, X., Choi, M. M., Milner, D. A., Venkatesh, D., et al. (2011). The $\beta$-glucan receptor dectin- 1 activates the integrin Mac- 1 in neutrophils via vav protein signaling to promote Candida albicans clearance. Cell Host Microbe 10, 603-615. doi: 10.1016/j.chom.2011.10.009

Lichtenstern, C., Herold, C., Mieth, M., Brenner, T., Decker, S., Busch, C. J., et al. (2015). Relevance of Candida and other mycoses for morbidity and mortality in severe sepsis and septic shock due to peritonitis. Mycoses 58, 399-407. doi: $10.1111 /$ myc. 12331

Liu, X., Wang, Q., Cui, S., and Liu, H. (2008). A new isolation method of $\beta$-d-glucans from spent yeast Saccharomyces cerevisiae. Food Hydrocoll. 22, 239-247. doi: 10.1016/j.foodhyd.2006.11.008

Liu, Y., and Filler, S. G. (2011). Candida albicans Als3, a multifunctional adhesin and invasin. Eukaryot. Cell 10, 168-173. doi: 10.1128/EC.00279-10

Lowell, C. A. (2011). Src-family and Syk kinases in activating and inhibitory pathways in innate immune cells: signaling cross talk. Cold Spring Harb. Perspect. Biol. 3, 1-16. doi: 10.1101/cshperspect.a002352

Masuko, T., Minami, A., Iwasaki, N., Majima, T., Nishimura, S.-I., and Lee, Y. C. (2005). Carbohydrate analysis by a phenol-sulfuric acid method in microplate format. Anal. Biochem. 339, 69-72. doi: 10.1016/j.ab.2004.12.001

Mayer, F. L., Wilson, D., and Hube, B. (2013). Candida albicans pathogenicity mechanisms. Virulence 4, 119-128. doi: 10.4161/viru.22913

Mohanty, T., Sjögren, J., Kahn, F., Abu-Humaidan, A. H. A., Fisker, N., Assing, K., et al. (2015). A novel mechanism for NETosis provides antimicrobial defense at the oral mucosa. Blood 126, 2128-2138. doi: 10.1182/blood-2015-04-641142

Monod, M., Hube, B., Hess, D., and Sanglard, D. (1998). Differential regulation of SAP8 and SAP9, which encode two new members of the secreted aspartic proteinase family in Candida albicans. Microbiology 144(Pt. 10), 2731-2737.

Mori, Y., Yamaguchi, M., Terao, Y., Hamada, S., Ooshima, T., and Kawabata, S. (2012). $\alpha$-Enolase of Streptococcus pneumoniae induces formation of neutrophil extracellular traps. J. Biol. Chem. 287, 10472-10481. doi: $10.1074 /$ jbc.M111.280321 
Murad, A. M., Lee, P. R., Broadbent, I. D., Barelle, C. J., and Brown, A. J. (2000). CIp10, an efficient and convenient integrating vector for Candida albicans. Yeast 16, 325-327. doi: 10.1002/1097-0061(20000315)16:4<325::AID-YEA538>3.0.CO;2-\#

Naglik, J., Albrecht, A., Bader, O., and Hube, B. (2004). Candida albicans proteinases and host/pathogen interactions. Cell. Microbiol. 6, 915-926. doi: $10.1111 / j .1462-5822.2004 .00439 . x$

Naglik, J. R. (2014). Candida immunity. New J. Sci. 2014, 1-27. doi: $10.1155 / 2014 / 390241$

Naglik, J. R., Challacombe, S. J., and Hube, B. (2003a). Candida albicans secreted aspartyl proteinases in virulence and pathogenesis. Microbiol. Mol. Biol. Rev. 67, 400-428. doi: 10.1128/MMBR.67.3.400-428.2003

Naglik, J. R., Moyes, D., Makwana, J., Kanzaria, P., Tsichlaki, E., Weindl, G. G., et al. (2008). Quantitative expression of the Candida albicans secreted aspartyl proteinase gene family in human oral and vaginal candidiasis. Microbiology 154, 3266-3280. doi: 10.1099/mic.0.2008/022293-0

Naglik, J. R., Rodgers, C. A., Shirlaw, P. J., Dobbie, J. L., Fernandes-Naglik, L. L., Greenspan, D., et al. (2003b). Differential expression of Candida albicans secreted aspartyl proteinase and phospholipase B genes in humans correlates with active oral and vaginal infections. J. Infect. Dis. 188, 469-479. doi: $10.1086 / 376536$

Nailis, H., Kucharíková, S., Ricicová, M., Van Dijck, P., Deforce, D., Nelis, H., et al. (2010). Real-time PCR expression profiling of genes encoding potential virulence factors in Candida albicans biofilms: identification of model-dependent and -independent gene expression. BMC Microbiol. 10:114. doi: 10.1186/1471-2180-10-114

Nanì, S., Fumagalli, L., Sinha, U., Kamen, L., Scapini, P., and Berton, G. (2015). Src family kinases and Syk are required for neutrophil extracellular trap formation in response to $\beta$-glucan particles. J. Innate Immun. 7, 59-73. doi: $10.1159 / 000365249$

Neeli, I., and Radic, M. (2013). Opposition between PKC isoforms regulates histone deimination and neutrophil extracellular chromatin release. Front. Immunol. 4:38. doi: 10.3389/fimmu.2013.00038

Negri, M., Botelho, C., Silva, S., Lopes, L. M. R. H., Henriques, M., Azeredo, J., et al. (2011). An in vitro evaluation of Candida tropicalis infectivity using human cell monolayers. J. Med. Microbiol. 60, 1270-1275. doi: 10.1099/jmm.0.031195-0

Netea, M. G., Gow, N. A. R., Munro, C. A., Bates, S., Collins, C., Ferwerda, G., et al. (2006). Immune sensing of Candida albicans requires cooperative recognition of mannans and glucans by lectin and Toll-like receptors. J. Clin. Invest. 116, 1642-1650. doi: 10.1172/JCI27114

Netea, M. G., Joosten, L. A., van der Meer, J. W., Kullberg, B. J., and van de Veerdonk, F. L. (2015). Immune defence against Candida fungal infections. Nat. Rev. Immunol. 15, 630-642. doi: 10.1038/nri3897

Nishinaka, Y., Arai, T., Adachi, S., Takaori-Kondo, A., and Yamashita, K. (2011). Singlet oxygen is essential for neutrophil extracellular trap formation. Biochem. Biophys. Res. Commun. 413, 75-79. doi: 10.1016/j.bbrc.2011.08.052

Parker, H., Dragunow, M., Hampton, M. B., Kettle, A. J., and Winterbourn, C. C. (2012). Requirements for NADPH oxidase and myeloperoxidase in neutrophil extracellular trap formation differ depending on the stimulus. J. Leukoc. Biol. 92, 841-849. doi: 10.1189/jlb.1211601

Pericolini, E., Gabrielli, E., Amacker, M., Kasper, L., Roselletti, E., Luciano, E., et al. (2015). Secretory aspartyl proteinases cause vaginitis and can mediate vaginitis caused by Candida albicans in mice. MBio 6, e00724-15. doi: $10.1128 / \mathrm{mBio} .00724-15$

Pietrella, D., Pandey, N., Gabrielli, E., Pericolini, E., Perito, S., Kasper, L., et al. (2013). Secreted aspartic proteases of Candida albicans activate the NLRP3 inflammasome. Eur. J. Immunol. 43, 679-692. doi: 10.1002/eji.2012 42691

Pietrella, D., Rachini, A., Pandey, N., Schild, L., Netea, M., Bistoni, F., et al. (2010). The Inflammatory response induced by aspartic proteases of Candida albicans is independent of proteolytic activity. Infect. Immun. 78, 4754-4762. doi: 10.1128/IAI.00789-10

Puri, S., Kumar, R., Chadha, S., Tati, S., Conti, H. R., Hube, B., et al. (2012). Secreted aspartic protease cleavage of Candida albicans Msb2 activates Cek1 MAPK signaling affecting biofilm formation and oropharyngeal candidiasis. PLoS ONE 7:e46020. doi: 10.1371/journal.pone.0046020

Ran, Y., Iwabuchi, K., Yamazaki, M., Tsuboi, R., and Ogawa, H. (2013). Secreted aspartic proteinase from Candida albicans acts as a chemoattractant for peripheral neutrophils. J. Dermatol. Sci. 72, 191-193. doi: 10.1016/j.jdermsci.2013.06.006

Rapala-Kozik, M., Bochenska, O., Zawrotniak, M., Wolak, N., Trebacz, G., Gogol, M., et al. (2015). Inactivation of the antifungal and immunomodulatory properties of human cathelicidin LL-37 by aspartic proteases produced by the pathogenic yeast Candida albicans. Infect. Immun. 83, 2518-2530. doi: 10.1128/IAI.00023-15

Rapala-Kozik, M., Karkowska-Kuleta, J., Ryzanowska, A., Golda, A., Barbasz, A., Faussner, A., et al. (2010). Degradation of human kininogens with the release of kinin peptides by extracellular proteinases of Candida spp. Biol. Chem. 391, 823-830. doi: 10.1515/bc.2010.083

Rochael, N. C., Guimarães-Costa, A. B., Nascimento, M. T. C., DeSouza-Vieira, T. S., Oliveira, M. F., Garcia e Souza, L. F., et al. (2015). Classical ROS-dependent and early/rapid ROS-independent release of Neutrophil Extracellular Traps triggered by Leishmania parasites. Sci. Rep. 5:18302. doi: 10.1038/srep 18302

Sanglard, D., Hube, B., Monod, M., Odds, F. C., and Gow, N. A. (1997). A triple deletion of the secreted aspartyl proteinase genes SAP4, SAP5, and SAP6 of Candida albicans causes attenuated virulence. Infect. Immun. 65, 3539-3546.

Scarborough, R. M., Naughton, M. A., Teng, W., Rose, J. W., Phillips, D. R., Nannizzi, L., et al. (1993). Design of potent and specific integrin antagonists. Peptide antagonists with high specificity for glycoprotein IIb-IIIa. J. Biol. Chem. 268, 1066-1073.

Schild, L., Heyken, A., de Groot, P. W. J., Hiller, E., Mock, M., de Koster, C., et al. (2011). Proteolytic cleavage of covalently linked cell wall proteins by Candida albicans Sap9 and Sap10. Eukaryot. Cell 10, 98-109. doi: 10.1128/EC.00210-10

Seweryn, K., Karkowska-Kuleta, J., Wolak, N., Bochenska, O., Kedracka-Krok, S., Kozik, A., et al. (2015). Kinetic and thermodynamic characterization of the interactions between the components of human plasma kinin-forming system and isolated and purified cell wall proteins of Candida albicans. Acta Biochim. Pol. 62, 825-835. doi: 10.18388/abp.2015_1142

Shibasaki, S., Aoki, W., Nomura, T., Miyoshi, A., Tafuku, S., Sewaki, T., et al. (2013). An oral vaccine against candidiasis generated by a yeast molecular display system. Pathog. Dis. 69, 262-268. doi: 10.1111/2049-632X.12068

Silva, N. C., Nery, J. M., and Dias, A. L. T. (2014). Aspartic proteinases of Candida spp.: role in pathogenicity and antifungal resistance. Mycoses 57, 1-11. doi: 10.1111/myc. 12095

Staniszewska, M., Bondaryk, M., Siennicka, K., Piłat, J., Schaller, M., and Kurzatkowski, W. (2012). Role of aspartic proteinases in Candida albicans virulence. Part I. Substrate specificity of aspartic proteinases and Candida albicans pathogenesis. Postępy Mikrobiol. 51, 127-135.

Tada, H., Nemoto, E., Shimauchi, H., Watanabe, T., Mikami, T., Matsumoto, T., et al. (2002). Saccharomyces cerevisiae- and Candida albicans-derived mannan induced production of tumor necrosis factor alpha by human monocytes in a CD14- and Toll-like receptor 4-dependent manner. Microbiol. Immunol. 46, 503-512. doi: 10.1111/j.1348-0421.2002.tb02727.x

Thomas, C. J., and Schroder, K. (2013). Pattern recognition receptor function in neutrophils. Trends Immunol. 34, 317-328. doi: 10.1016/j.it.2013.02.008

Urban, C. F., Ermert, D., Schmid, M., Abu-Abed, U., Goosmann, C., Nacken, W., et al. (2009). Neutrophil extracellular traps contain calprotectin, a cytosolic protein complex involved in host defense against Candida albicans. PLoS Pathog. 5:e1000639. doi: 10.1371/journal.ppat.1000639

Urban, C. F., Reichard, U., Brinkmann, V., and Zychlinsky, A. (2006). Neutrophil extracellular traps capture and kill Candida albicans yeast and hyphal forms. Cell. Microbiol. 8, 668-676. doi: 10.1111/j.1462-5822.2005.00659.x

van Bruggen, R., Drewniak, A., Jansen, M., van Houdt, M., Roos, D., Chapel, H., et al. (2009). Complement receptor 3, not Dectin-1, is the major receptor on human neutrophils for beta-glucan-bearing particles. Mol. Immunol. 47, 575-581. doi: 10.1016/j.molimm.2009.09.018

Ward, C., Walker, A., Dransfield, I., Haslett, C., and Rossi, A. G. (2004). Regulation of granulocyte apoptosis by NF-кB. Biochem. Soc. Trans. 32, 465-467. doi: $10.1042 /$ bst0320465

Wellington, M., Dolan, K., and Krysan, D. J. (2009). Live Candida albicans suppresses production of reactive oxygen species in phagocytes. Infect. Immun. 77, 405-413. doi: 10.1128/IAI.00860-08

Whitlock, B. B., Gardai, S., Fadok, V., Bratton, D., and Henson, P. M. (2000). Differential roles for $\alpha_{M} \beta_{2}$ integrin clustering or activation in the control of apoptosis via regulation of akt and ERK survival mechanisms. J. Cell Biol. 151, 1305-1320. doi: 10.1083/jcb.151.6.1305 
Wu, H., Downs, D., Ghosh, K., Ghosh, A. K., Staib, P., Monod, M., et al. (2013). Candida albicans secreted aspartic proteases 4-6 induce apoptosis of epithelial cells by a novel Trojan horse mechanism. FASEB J. 27, 2132-2144. doi: 10.1096/fj.12-214353

Yipp, B. G., Petri, B., Salina, D., Jenne, C. N., Scott, B. N. V., Zbytnuik, L. D., et al. (2012). Infection-induced NETosis is a dynamic process involving neutrophil multitasking in vivo. Nat. Med. 18, 1386-1393. doi: 10.1038/nm.2847

Zanoni, I., Ostuni, R., Marek, L. R., Barresi, S., Barbalat, R., Barton, G. M., et al. (2011). CD14 controls the LPS-induced endocytosis of Toll-like receptor 4. Cell 147, 868-880. doi: 10.1016/j.cell.2011.09.051

Zhou, M. J., and Brown, E. J. (1994). CR3 (Mac-1, alpha M beta 2, CD11b/CD18) and FC gamma RIII cooperate in generation of a neutrophil respiratory burst: requirement for Fc gamma RIII and tyrosine phosphorylation. J. Cell Biol. 125, 1407-1416. doi: 10.1083/jcb.125.6.1407
Conflict of Interest Statement: The authors declare that the research was conducted in the absence of any commercial or financial relationships that could be construed as a potential conflict of interest.

The reviewer FA and handling Editor declared their shared affiliation.

Copyright (c) 2017 Zawrotniak, Bochenska, Karkowska-Kuleta, Seweryn-Ozog, Aoki, Ueda, Kozik and Rapala-Kozik. This is an open-access article distributed under the terms of the Creative Commons Attribution License (CC BY). The use, distribution or reproduction in other forums is permitted, provided the original author(s) or licensor are credited and that the original publication in this journal is cited, in accordance with accepted academic practice. No use, distribution or reproduction is permitted which does not comply with these terms. 